\title{
プラスチックワイヤーについて
}

日本フィルコン株式会社技術第一部 小 林 民 雄

\section{All sorts of characteristics of forming fabric for paper-making}

\author{
Tamio Kobayashi \\ Nippon Filcon Co., Ltd.
}

Recently remarkable progress is seen in paper-making technology to pursue higher papermaking efficiency, better paper quality and working efficiency.

Forming fabric is indispensable to paper machine in its wet end and so there are great requirements for forming fabric being best matched to paper-making conditions.

As the result, many kinds of designs in forming fabrics are appearing and used practically and $\mathrm{R} \& \mathrm{D}$ are continued.

This discription relates developing process of forming fabric regarding its characteristics and conditions to be reqiured for paper-making.

\section{はじめに}

抄紙用ワイヤーは抄紙機のウェットパートに欠くこ とのできない重要な用具で，過去にワイヤーは金網と 呼ばれる金属ワイヤーが長期間にわたり使用されてき たが, 1960 年代中頃よりプラスチックワイヤーが実用 化されるにいたり，徐々に金属ワイヤーに代りその使 用が増加してきた。

その間，製紙技術の目ざましい進歩にともない，抄 紙機は大型化, 高速化とともに各種新型のフォーマー が出現し, 一方, 紙も市場ニーズの拡大につれて品質 の高度化, 多様化が行われ, それに応じてワイヤーに 対する要求も高まり, 研究開発の結果, 1980 年代に各 種の多重織が実用化されるに及んで, 抄紙適性, 選択 範囲の拡大によりその使用は加速されてきた。

1989 年の実績では使用面積 $65 \%$, 転換率は仮に平均 寿命を金属ワイヤーのそれの 5 倍とする $92 \%$ 迄達し ており，プラスチックワイヤーが抄紙用ワイヤーの主 要な座を占めたと言っても過言でない。

しかし今後，抄紙機を始めとして製紙技術は益々進 歩発展を続けることが考えられ，それに伴いワイヤー に対する要求も品種の多様化, 諸特性ならびに品質精 度の高度化等, 益々繳しくなることが予想される。

ここでは抄紙用ワイヤーに要求される諸条件と特性
の関係について概要を述べ参考に供したい。

\section{1. 抄紙用ワイヤーの機能}

抄紙用ワイヤーは抄紙上でエンドレスのベルト状に 張られ，高速に回転し負荷変動を受けながら，ストッ クインレットからのパルプスラリーを受け, 地合形成 を行いつつ脱水し, 次のパートへ運搬する重要な役割 を持つが, 抄造品種および条件に適合した抄紙適性と 動力伝達性を有することはもちろん, 消耗品であるた め, 長時間の使用に耐える経済性も操業安定と共に強 く要求される。

そのため抄紙用ワイヤーに要求される諸条件として は

(1)機械的強度があること

(2)表面密度が高く, 纎維支持性および表面平滑性があ ること

(3)適性な沪水性があること

(4)耐摩耗性がよいこと

(5)洗浄効果がよいこと

(6)走行安定性, 寸法安定性があること

(7)保水性が少ないこと

(8)均一性があること

(9)耐腐蝕性があること 等が挙げられる。 


\section{2. プラスチックワイヤーについて}

\section{1 材 質}

プラスチックワイヤーはその材質が高分子系であり, 現在ポリエステルが機械的性質, 材質ならびに寸法安 定性の優位性から広く使用されている。しかし耐摩耗 性に若干難があるため，吸水性を有するため機械的性 質，安定性はポリエステルに及ばないが，耐摩耗性に 特に優れたポリアミドが目的に応じて使用される。

表 1 に線材の物性を示す。

\section{2 プラスチックワイヤーの性質}

金属ワイヤーに比較すると材質から

(1)材質の比重が低い（ポリエステル：1.38，ポリアミ

ド : 1.14)

(2)限定された範囲で弾性回復性があるため耐疲労性に

優れている

表 1 プラスチックワイヤーに使用される線材の物性

\begin{tabular}{|c|c|c|}
\hline 項 & ポリエステル & ポリアミド \\
\hline 強度 $\mathrm{kg} / \mathrm{mm}^{2}$ & $35-70$ & $24-46$ \\
\hline 伸率 \% & $16-40$ & $20-70$ \\
\hline 比重 & 1.38 & 1.14 \\
\hline $24 \mathrm{H}$ 吸水率 $\%$ & 0.2 & 2.9 \\
\hline 酸の影響 & $\begin{array}{l}\text { ほとんどの無機酸 } \\
\text { に強い }\end{array}$ & $\begin{array}{l}5 \% \text { 塩酸で煮沸す } \\
\text { ると分解, 他の酸 } \\
\text { にも影響を受ける }\end{array}$ \\
\hline $\begin{array}{l}\text { アルカリ } \\
\text { の影響 }\end{array}$ & $\begin{array}{l}\text { 弱アルカリに強い } \\
\text { 強アルカリには } \\
\text { 徐々に作用される }\end{array}$ & ほとんど変化なし \\
\hline
\end{tabular}

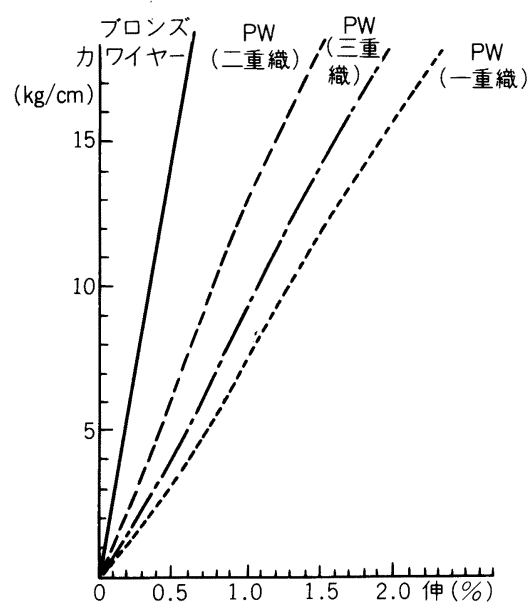

図 1 各種ワイヤーの強伸度曲線
(3)耐摩耗性がよい

(4)一般抄紙条件下では耐蝕性がある

等を有するため, 取扱い等作業性および金属ワイヤー 使用時に発生する永久变形, 疲労からくる諸問題から も解放されるため長寿命と操業安定性が期待できる。

さらに金属ワイヤーでは限定されていたが，その線 材から各種の織組織の製作が可能で抄造品種, 条件に たいして選定範囲が広い利点を持っている。

しかし一方材質的に

(1)伸び特性，剛性に難がある（図 1 参照）

(2)ポリエステルの場合, 線材自体溌水性を有するため,

それに起因する污れ等の問題がある

等の欠点をもつため，プラスチックワイヤーのデザイ ン，製作に当たってはこれらの点を上手に調和させ， 目的に応ずることが重要で, 充分考虑して行われる。

\section{3 プラスチックワイヤーの種類}

プラスチックワイヤーは前述のように各種の織組織 の製作か可能であるため，抄紙用ワイヤーに要求され る諸特性を改善する目的で研究開発された結果，現在， 1 重織, 多重織 ( 2 重織, 2.5 重織, 3 重織) が抄紙機 および抄紙条件に応じて使用されている。

表 2〜 5 に現在実用化されている代表的なプラス チックワイヤーの各組織と品種ならびに表 6 に線材の 組合せを示している。

(1) 1 重織

エンドレス方法から織継品 (記号 $\mathrm{H}$ ), 袋織品 (記号 R）の 2 種があり，共に差異なく使用されている。

線材は縦横線ともポリエステルを使用するのが一般 的で，その他，横線にポリアミドを交織したもの，縦 横線とも全てポリアミドを使用したものもあるが, こ れらは主に板紙抄造用として使用されている。

諸特性に優れた 4 シャフトブロークンサテン織が広 範囲に，4 シャフトレベル織は板紙抄造用， 5 シャフ トサテン織はティシュ抄造用としてそれぞれ使用され ている。

現在，多重織への転換が進んでいるが，初期の沪水 性, 保水性, 洗浄性, 経済性等の利点を考虑して使用 されている。

\section{(2) 2 重織}

その構造は縦線を目空きが見えないくらいに密集さ せ，横線は上下それぞれの目的，すなわち上横線は紙 質を, 下横線は耐摩耗性を考虑して配した横二重織で ある。

エンドレス方法は織継ぎで行い, 線の組合わせにつ いては表 6 に示したが，摩耗面にポリアミドを交織す るのが普通である。 
表 21 重織一覧表

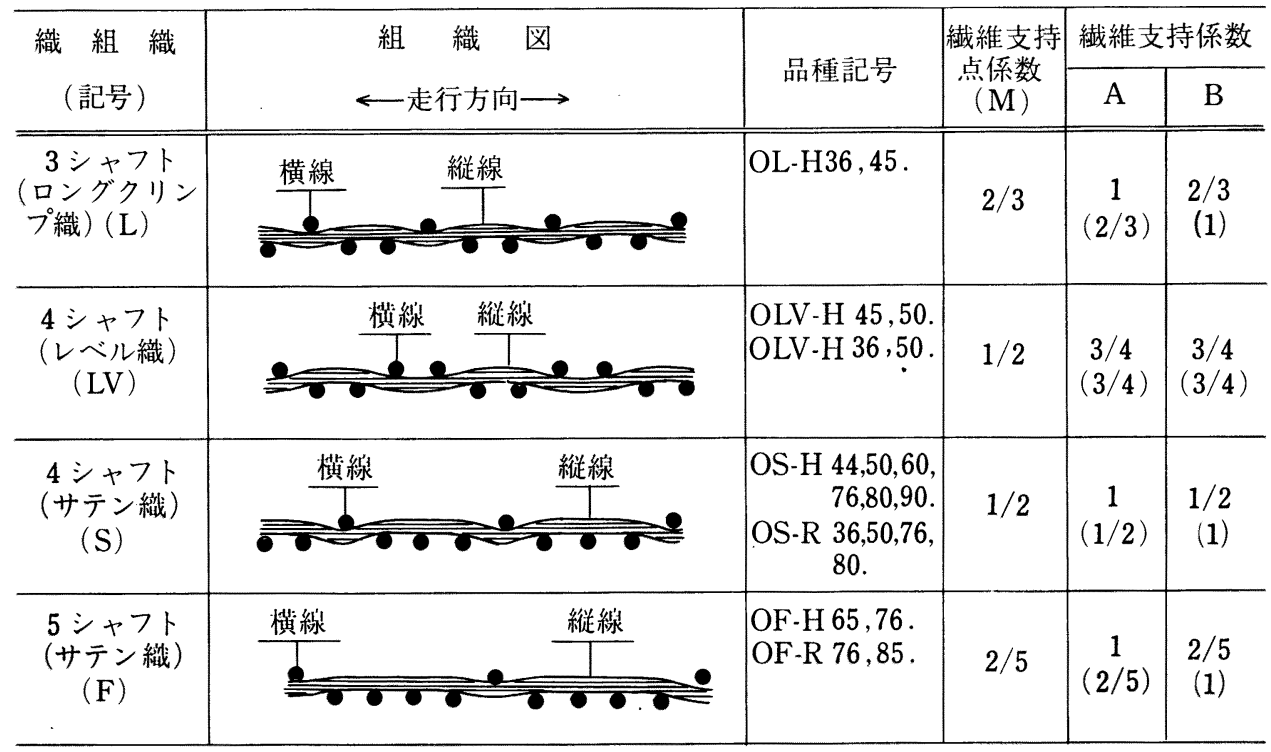

（）内縦摩耗型の場合

表 32 重織一覧表

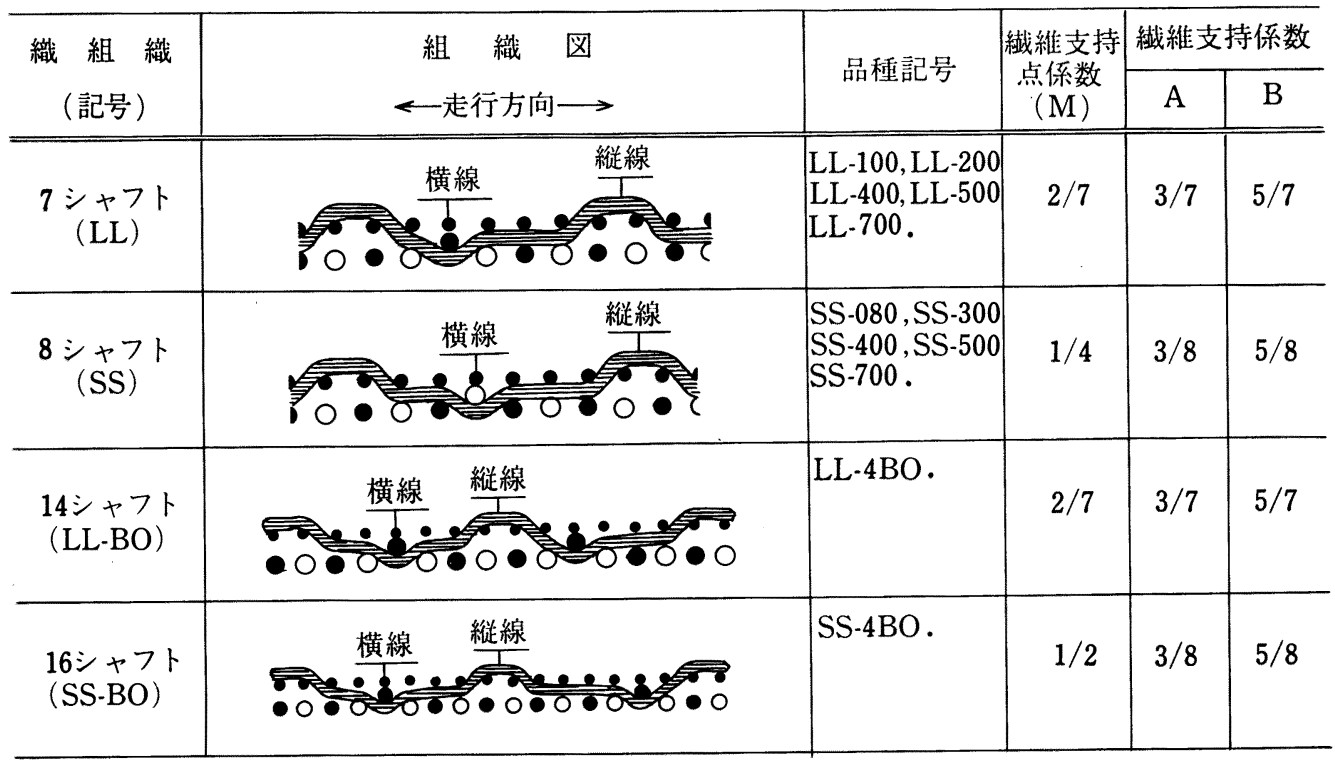

7 シャフト， 8 シャフトが多く使用されているが, 後述する諸特性から 7 シャフトは表面性, 剛性を要求 される場合, 8 シャフトは表面性, 剛性に若干難があ るが, 沪水性, 耐摩耗性に優位性があるためその使用 は現在も多い。

14 シャフト, 16 シャフトは下横線をロングナックル （写真 1 参照）にして耐摩耗性向上を図ったものであ が, ワイヤーマークの問題もあるため現在は限定され
た範囲で使用されている。

(3) 2.5 重織

2 重織の繊維支持性を改善したもので, 従来の上横

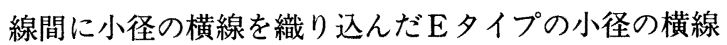

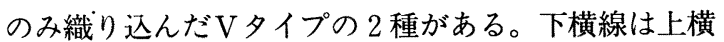
線本数の $1 / 2$ と少なく配し, 沪水のためボイドスペー スを確保している。

各シャフトの特性は 2 重織に準じるが, 現在効果が 
表 42.5 重織一覧表

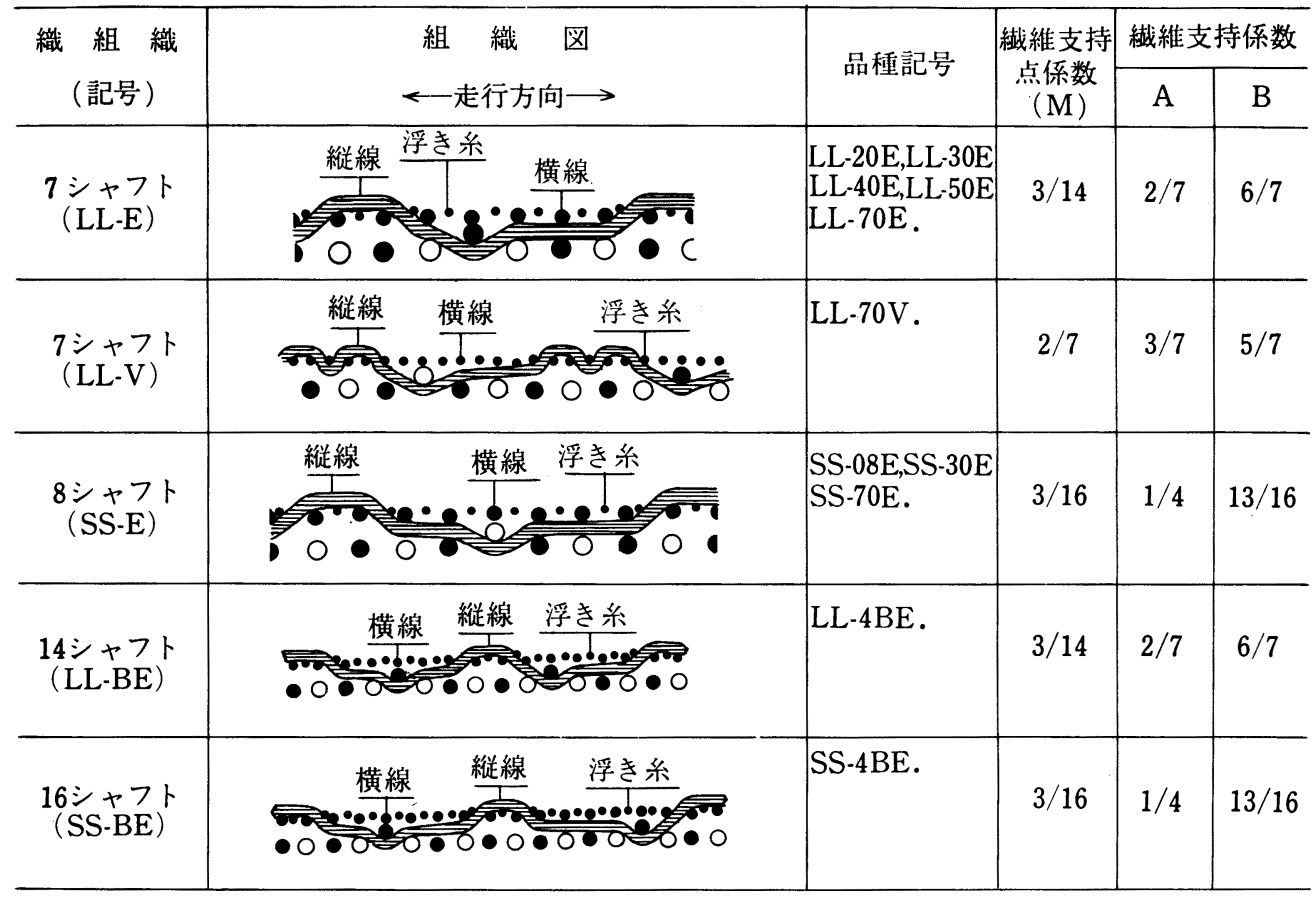

表 53 重織, 特殊 3 重織一覧表

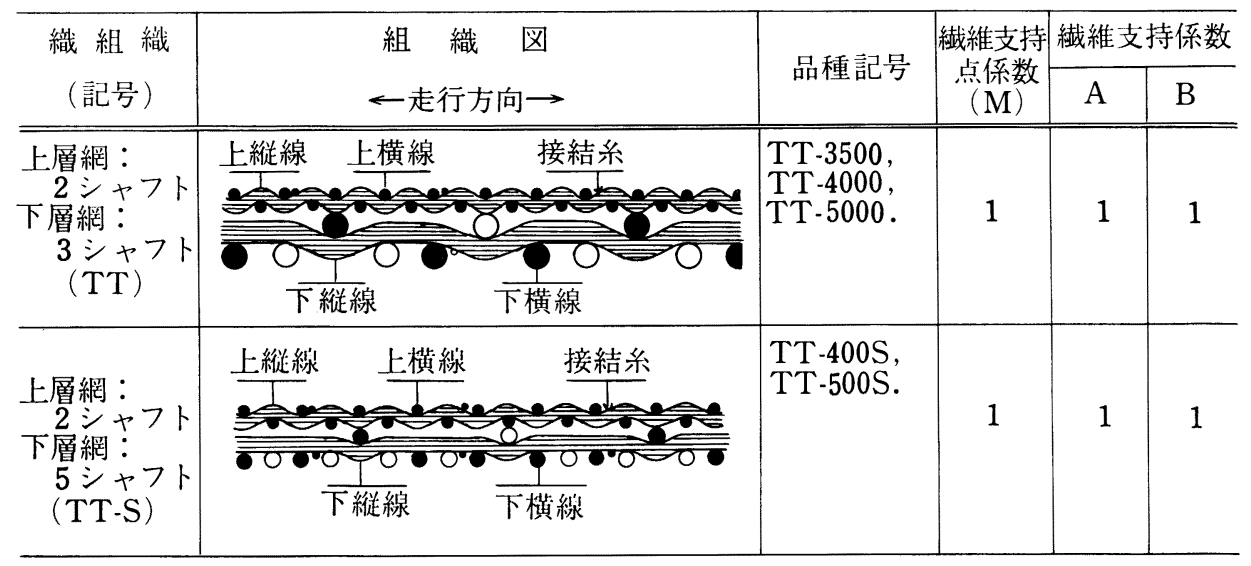

表 6 抄紙用プラスチックワイヤーの線材組合せ

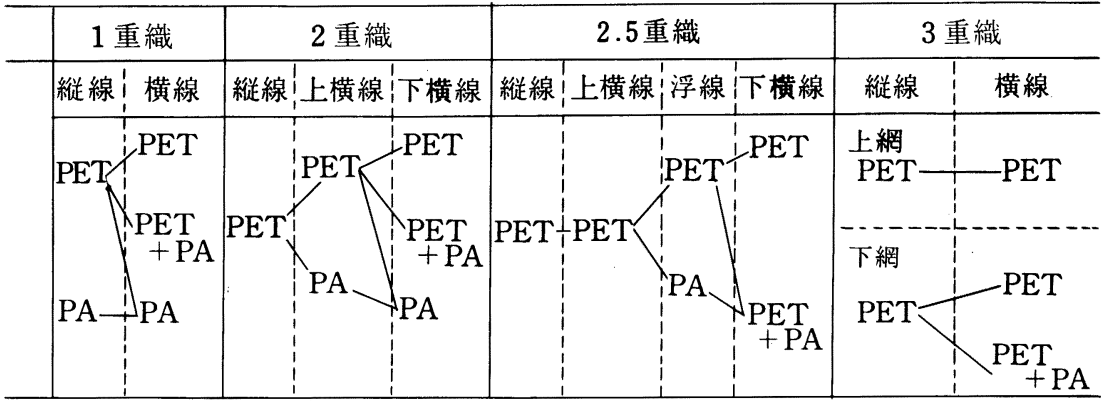

注） PET：ポリエステル, PA:ポリアミド 


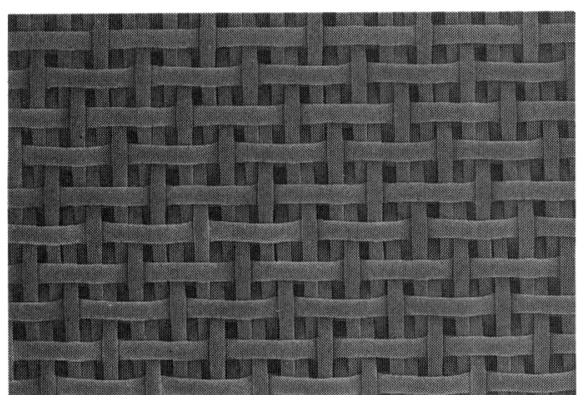

SS-400（2 重織：8シャフト)

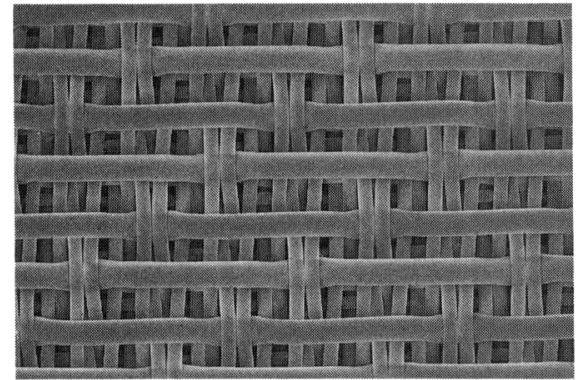

$\mathrm{SS}-4 \mathrm{BE}$ (2.5 重織：16 シャフト)

写真 1 ワイヤー摩耗面の拡大写真
認められ 7 シャフト， 8 シャフトを主にその使用は急 増している。

(4) 3 重織

その構造は上下の網をそれぞれの目的に応じて，す なわち上層網は紙質を，下層網は機械的特性と耐摩耗 性を考虑してデザインし，接結糸で上下層網を固定し た 2 層織物である。一般に上層網は繊維支持性の最も 良い平織( 2 シャフト), 下層網は目的により 1 重織の 組織の中より選ばれる。

材質は下層網横線にポリアミドを交織するのが一般 的である。

下層網の目数は縦線は上層網の $1 / 2$, 横線は一般的 には $1 / 2$ であるが, 同一本数まで変化させることがで きる。最近，上下層網とも同一目数の特殊 3 重織が実 用化され使用されている (写真 2 参照)。

以上のようにアイディアとしては理想的なワイヤー であるが，接結糸の配置ならびに下層網の脱水パ夕ー ンによるマークの発生, 接結糸の摩耗切れによる上下 層網の剝離，上下層網間の摩耗による組織の緩み，保 水性の問題も一部発生しており, これ等の改善も重要 である。一方，価格等の経済効果もあるため, 現在そ の使用はあまり増加していない。
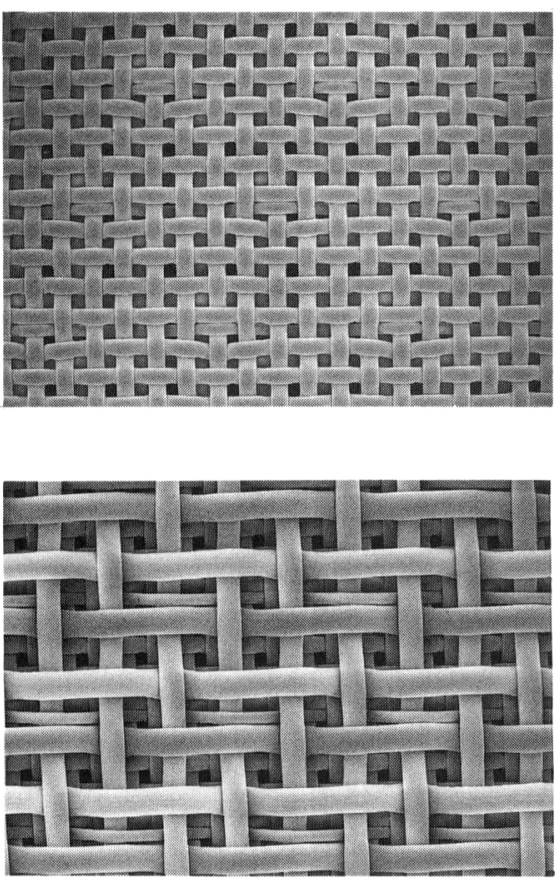

TT-4000 ( 3 重織)
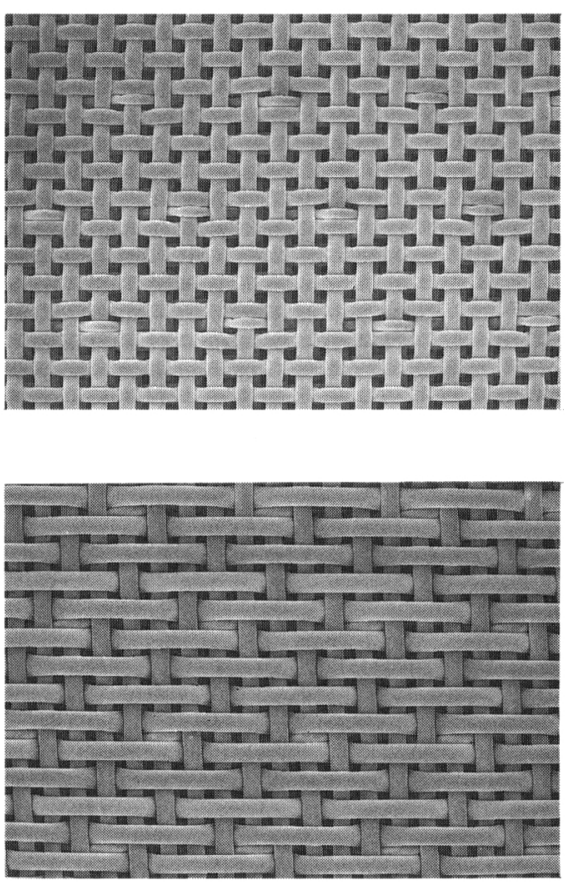

TT-400 S (特殊 3 重織)

写真 23 重織および特殊 3 重織表裏拡大写真 


\section{3. プラスチックワイヤーの諸特性}

\section{1 伸び特性, 剛性}

抄紙用ワイヤーの伸び特性，剛性は紙質ばかりでな く操業性に関わる重要なファクターである。

すなわち伸び特性，剛性の悪いワイヤーは外力によ 万影響を受けやすく，例之ば図 2 の如く脱水機器間で の撓み量が多くなり，過度な脱水と脈動の発生やス トックジャンプによる地合およびワイマーク等紙質に 影響を与えるばかりでなく，ドラックロードの増加， スリップ発生による負荷上昇，スリップ，クリープお よび脱水機器への接触過多による摩耗の進行, その他, 幅縮みや変形などからくる操業性への影響もある。

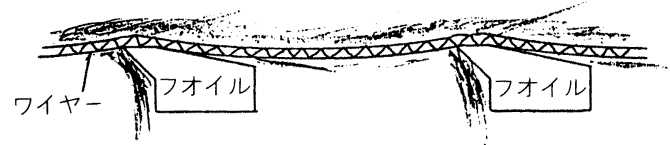

図 2 脱水力によるワイヤーの撓み
プラスチックワイヤーは金属ワイヤーに比較すると 材質から伸び特性，剛性に難があるため，その構造に ついては下記の点を考虑してデザイン，製作される。 (1)縦線のクリンプ量を少なくして構造伸びを抑制する (2)縦横線の単位断面積密度を高め, 伸び特性, 剛性の 改善を図かる

(3)縦線の摩耗を防ぐ構造とし，縦線の断面積減少によ る伸びを抑制する（横線摩耗型）

(4)単位組織内の縦横線の接結数を多くする

(5)綾の変更により組織剛性を高める

(6)組織内の線間の緊張状態を確保し，外力による変形 量を最小限に留まるようにすると同時に回復性を高 める

表 7 に代表的プラスチックワイヤーの伸び特性，剛性 評価値を示した。

(1) 1 重織

表 1 のように縦線の垂直方向のクリンプを少なくし, 本数も横線のそれより多くして構造による伸び特性に 対処している。

表 7 各種ワイヤーの伸び特性, 剛性関係数值比較表

\begin{tabular}{|c|c|c|c|c|}
\hline 品 & OS-H 80 & SS-400 & $\mathrm{LL}-40 \mathrm{E}$ & $\mathrm{TT}-400 \mathrm{~S}$ \\
\hline シャフト数 & 4 シャフト & 8 シャフト & 7 シャフト & $\begin{array}{l}\mathrm{U} ： 2 \text { シャフト, } \\
\mathrm{L}: 5 \text { シャフト }\end{array}$ \\
\hline 径 & $0.175 / 0.20$ & $\begin{array}{l}0.17 / 0.17 \\
/ 0.22,0.22 \mathrm{~N}\end{array}$ & $\begin{array}{l}0.17 / 0.13,0.17 \\
/ 0.22,0.22 \mathrm{~N}\end{array}$ & $\begin{array}{l}0.17 / 0.16 \\
0.20 / 0.22,0.22 \mathrm{~N}\end{array}$ \\
\hline 数 & $91 / 60$ & $155 / 58 \times 2$ & $155 / 90 \times 1.5$ & $70 / 70,70 / 70$ \\
\hline $\begin{array}{l}\text { 縦線断面積 } \\
\left(\mathrm{mm}^{2} / \text { 吋 }\right)\end{array}$ & 2.1877 & 3.5164 & 3.5164 & 3.7860 \\
\hline $\begin{array}{l}\text { 横線断面積 } \\
\left(\mathrm{mm}^{2} / \text { 吋 }\right)\end{array}$ & 1.8840 & 3.5194 & 3.8975 & 4.0663 \\
\hline $\begin{array}{c}\text { 断面 積 比 } \\
(\text { 縦/横) }\end{array}$ & 1.161 & 0.999 & 0.902 & 0.931 \\
\hline $\begin{array}{l}\text { 組織線密度 } \\
\left(\mathrm{cm}^{3} / \mathrm{m}^{2}\right)\end{array}$ & 179 & 301 & 360 & 351 \\
\hline $\begin{array}{l}\text { 伸 び 係 数 } \\
(7 \mathrm{~kg} / \mathrm{cm})\end{array}$ & 1.05 & 0.75 & 0.70 & 0.90 \\
\hline B S 值 & 2.70 & 3.80 & 2.60 & 1.80 \\
\hline
\end{tabular}

注） BS 值は綾方向の伸び係数でワイヤー対角線上に一定の張力をかけたときの各対 角線の伸び率の平均值で表わす。

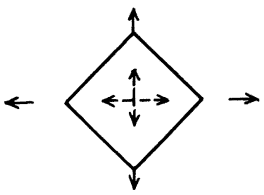




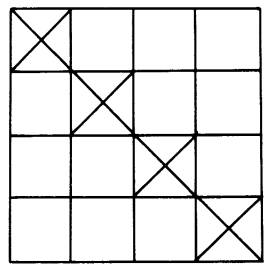

4 シャフト織

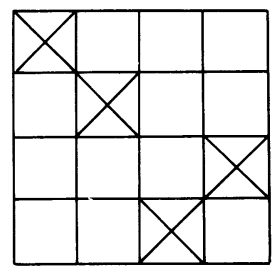

4シャフトブロークンサテン織
図 34 シャフトサテン織組織困

広く使用されている 4 シャフトサテン織は綾組織を 図3のように崩すことにより, 綾方向の緩みを改善し ており，ブロークンサテン織とも呼ばれている。

(2) 2 重織

構造から縦横線の単位断面積密度が高く, そのため 単位組織内の線密度も増加するので線間の緊張度が高 まるため，伸び特性，剛性とも向上する。

表 3 には各織組織とも広く使用されている横線摩耗 型を示しているが, 各シャフトは種々の織組織の生産 が可能で, 例として表 8 に 7 シャフトの各種織組織を 参考に示した。

縦横線の単位組織内の接結数が多いほど風性には有 利であるが, 表面性, 沪水性, 摩耗形態を考虑して目 的に応じて選択される。

7 シャフトと 8 シャフトの比較では表 3 に示す如く, 標準品では縦横線の接結形態が同じであるため，同一 目数の場合, 単位面積内の接結数が少ない 8 シャフト は剛性面で若干不利になる。

14 シャフト, 16 シャフトについてもそれぞれ 7 シャ フト，8シャフトの性質に準ずると考えてよい。

\section{(3) 2.5 重織}

表 4 に示す如く，横線密度が増加すると同時に単位 組織内の接結数も多くなるので, 剛性は 2 重織より有 利である。

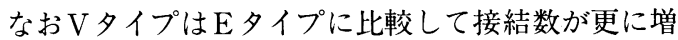
加するため剛性効果は大きい。

(4) 3 重織

構造から縦横線の単位断面積密度及び単位組織内の 縦横線の接結数が多いため最も剛性がある。
表 87 シャフトの各種織組織

\begin{tabular}{|c|}
\hline$\longleftarrow$ 走行方向 $\longrightarrow$ \\
\hline 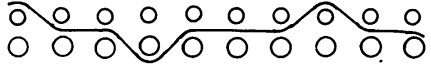 \\
\hline 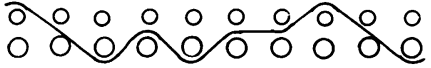 \\
\hline $\begin{array}{llllllllll}0 & 0 & 0 & 0 & 0 & 0 & 0 & 0 & 0 & 0 \\
0 & 0 & \ddots & 0 & 0 & 0 & 0 & 0 & 0 & 0\end{array}$ \\
\hline 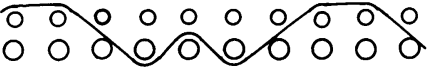 \\
\hline 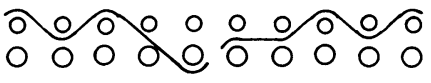 \\
\hline $\begin{array}{llllllllll}0 & 0 & 0 & 0 & 0 & 0 & 0 & 0 & 0 & 0 \\
0 & 0 & 0 & 0 & 0 & 0 & 0 & 0 & 0 & 0\end{array}$ \\
\hline
\end{tabular}

表 9 樹脂加工の剛性効果

\begin{tabular}{c|c|c}
\hline \multirow{2}{*}{ ワイヤ一品種 } & \multicolumn{2}{|c}{$\mathrm{SS}-400$} \\
\cline { 2 - 3 } & 未加工品 & 樹脂加工品 \\
\hline 伸び係数 & 0.75 & 0.70 \\
\hline $\mathrm{B} S$ 值 & 3.80 & 0.30 \\
\hline
\end{tabular}

伸び特性は上下網のバランスの関係上， 2 重織に比 較すると若干低下する。

摩耗進行による剛性変化は図 4 に示すように 1 重織 は多重織に比較して, 総体線断面積密度の減少が多い ため影響が大きい。

以上, ワイヤー構造と伸び特性, 剛性について述べ たが線材の性質から限界もある。

そのため他の改善手法としては樹脂加工がある。こ れは縦横線の接結部を樹脂で固定するため, 表 9 に示 した如く，綾方向の剛性改善に効果が大きい。

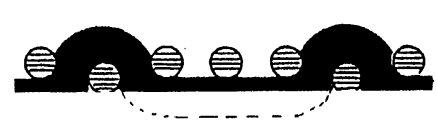

4 シャフトサテン織

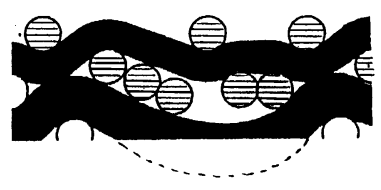

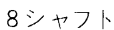

図 4 ワイヤーの摩耗による断面積減少状況 


小林层雄

一方，使用サイドにおいてはテンション管理は重要 である。適正テンションを維持することはワイヤーの 組織緊張度を保持することであり，伸び，剛性ばかり でなく，動力伝達性を始めとした諸特性にも効果があ る。

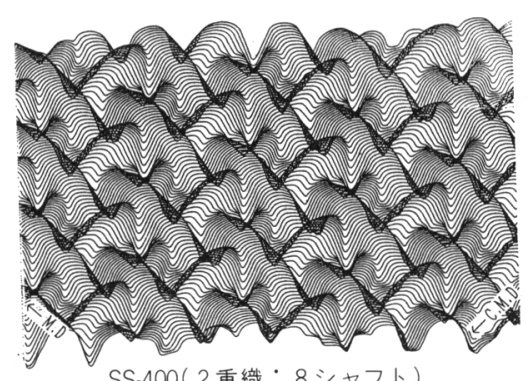

SS-400( 2 重織：8シャフト)

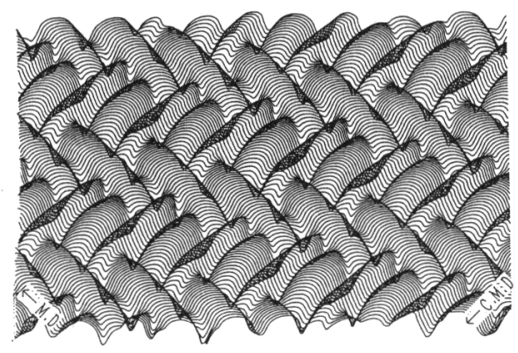

LL-40E(2.5 重織：7シャフト)

\section{2 ワイヤーの表面性}

ワイヤーの表面には縦横線のナックルと繊維支持形 態によって形成された叫がある。これらは紙質，リ テンションばかりでなくワイヤーのその他要求される 諸条件にも関わりがあるため重要である。

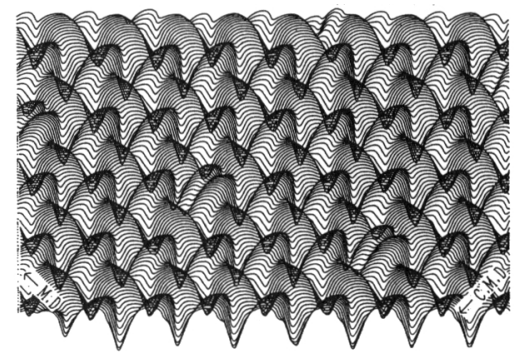

TT-400S(特殊 3 重織)

図 5 各種ワイヤーの表面三次元粗さ

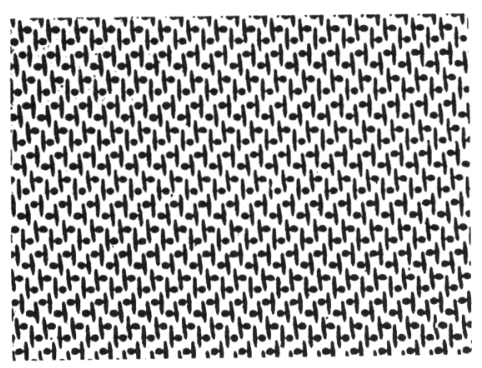

CS-H80(1重織：4シャフトサテン織)

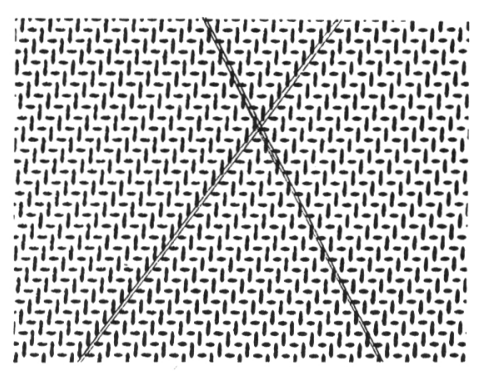

LL-500(2重織：7シャフト)

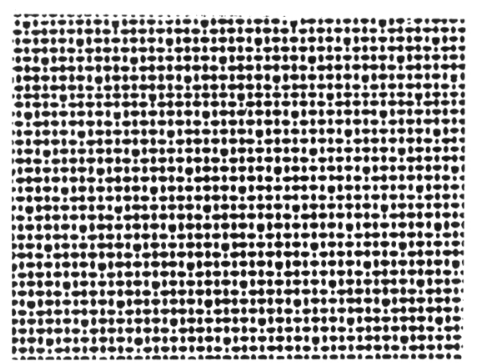

TT-400S(特殊 3 重織)

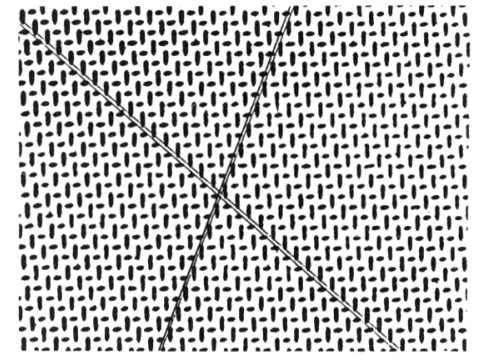

SS-500(2重織：8シャフト)

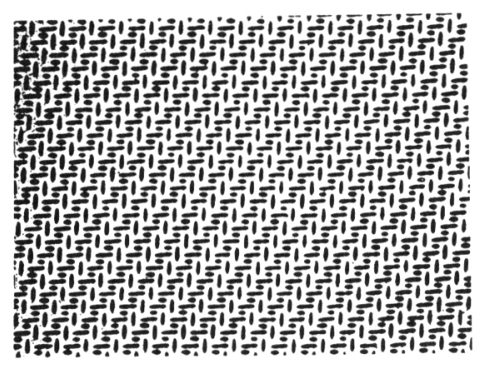

LL.40E(2.5重織：7シャフト)

図 6 各種ワイヤーの表面プリントマーク拡大困 
図 5 は各種プラスチックワイヤーの表面三次元粗さ を調査したものであるが,ナックルによって形成され た表面の凹凸状況が分かる。図 6 はワイヤーの表面プ リントマークを拡大したものであるが，ワイヤー表面 の繊維支持面積と空間面積との関係および織組織固有 の綾パターンが見られる。

写真 3 はワイヤー表面拡大写真に黒線で繊維支持形 態を記入したものであり, 図 7 はその状況を図式化し ている。織組織固有のフレームが形成されており, フ レーム内には表面空間部が形成されている。

一般にワイヤー表面のナックルによって形成された 凹部は紙面の平滑性とワイヤーマークに影響するため,

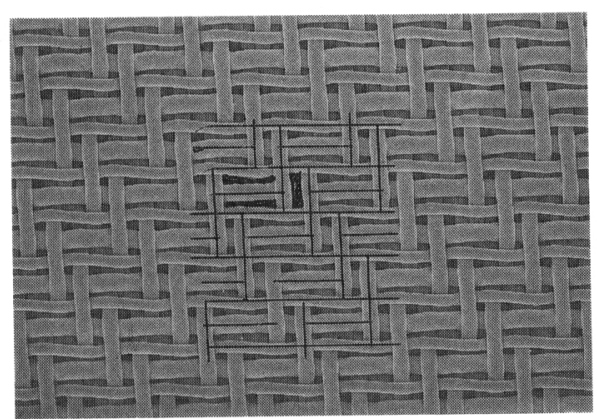

LL-40E（2.5 重織：7シャフト)

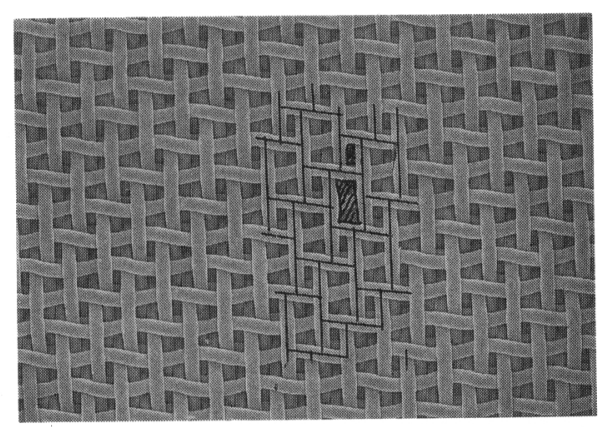

SS-500（2 重織：8シャフト)

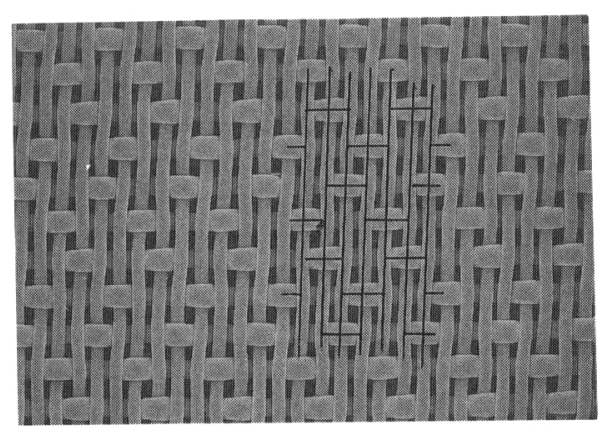

OS-H 80 (1 1 重織：4 シャフトサテン織）
デザイン，製作にあたっては図８のようにナックル上 面をイーブンナックルに近づけ，図6内に書き込まれ たライン間の溝の幅及び深さを小さくなるようにする。 当然ファインメッシュのワイヤーは使用線径が細くな るため，表面平滑性の向上には有利である。

改善方法としては表面研磨がある。これはワイヤー 表面平滑性, 繊維支持面積, シートレリースの向上に 効果的である。

しかし重要なことはワイヤー表面の緘維支持形態に ある。すなわち紙層は水を媒体として形成されるため, 水流方向に繊維は配向したがる性質を有し, 初期脱水 時には特に傾向が強い。

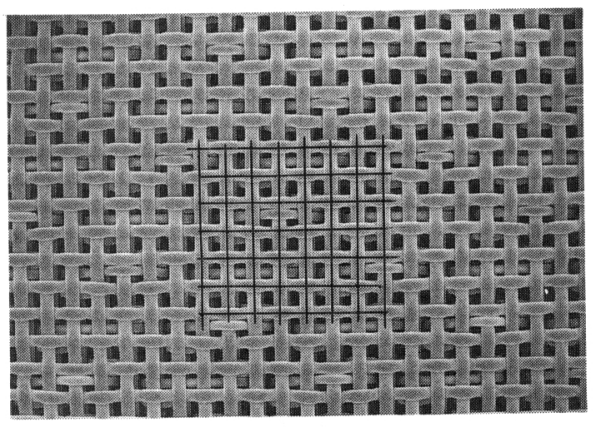

TT-400S（特殊 3 重織）

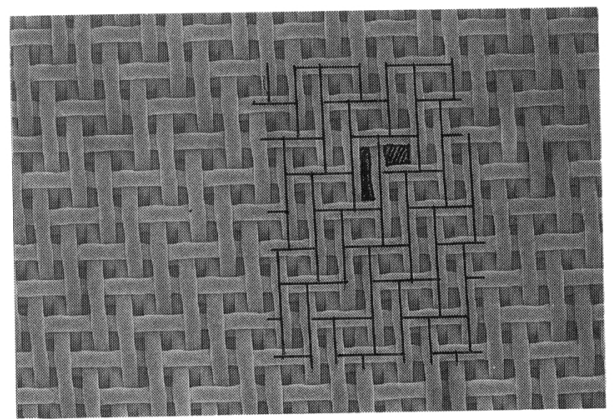

LL-500（2 重織： 7 シャフト)

写真 3 各種ワイヤー表面拡大写真 


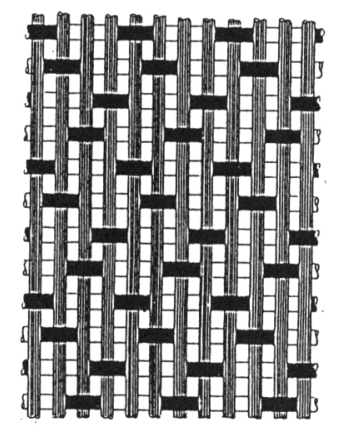

OS-H80(1重織：4シャフトサテン織)

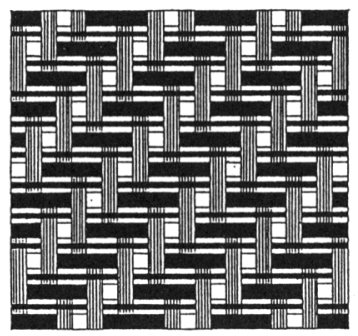

LL-40E(2.5重織：7シャフト)

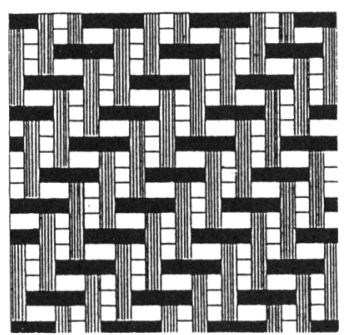

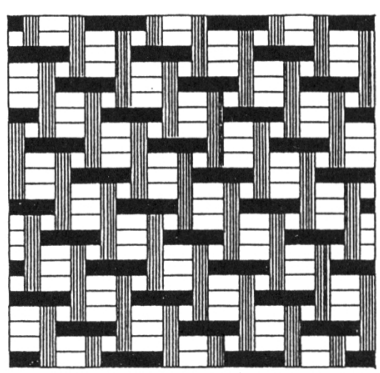

SS-500(2重織：8シャフト)

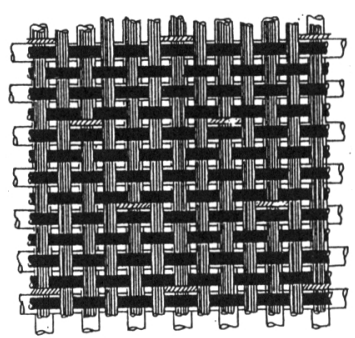

TT-4000( 3 重織)

LL-500(2重織：7シャフト)

図 7 各種ワイヤー表面空間状況困

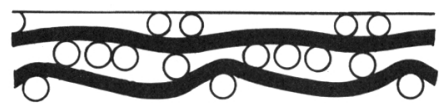

ノンイーブンナクウル

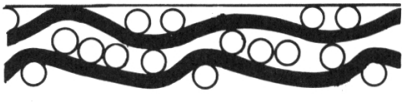

イーブンナックル

図 8 イーブンナックル状況 ( 2 重織： 7 シャフト)

ワイヤ一面に着地した繊維は初期の加圧脱水とその 後の吸引脱水等により図 9 のように線間で撓む。支点 間距離が長いほど撓み量は多くなり, 支持されない微 細纎維等は目空き空間を通して流出したり, またワイ ヤ一組織内への刺り込み, 滞留等の現象が発生しやす い。これらは紙面の平滑性, ワイヤーマーク, リテン ションに影響するばかりでなく, 沪水性の低下とそれ による地合不良, 摩耗の増進, ドラッグロード増加に

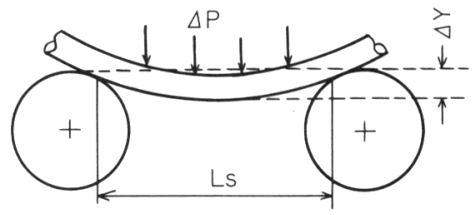

図 9 ワイヤー上での繊維の撓み 
よる負荷上昇，シートレリース不良等の各種の弊害が 発生しやすい。故にワイヤーの表面繊維支持形態の改 善はワイヤーにとって重要な課題であり, 現状多くの ワイヤーが開発されて来な。

ワイヤ一表面の評価方法としては，一般に表面刷り マーク，プリントマーク，三次元粗さ測定，拡大写真 等視覚によるものと，下記に示す各種数值によるもの がある。

(1)繊維支持点間距離：Ls（図 10 参照）

(2)単位組織内最大表面空間寸法 : $K_{x}, K_{y}$ (図 10 参照)

(3)単位面積 $\left(1 \mathrm{~cm}^{2}\right)$ あたりの繊維支持点数： $\mathrm{T}_{\mathrm{x}}$

計算は次式で行う。

$$
\begin{aligned}
& \mathrm{T}_{\mathrm{x}}=0.155 \times \mathrm{N}_{\mathrm{x}} \times \mathrm{N}_{\mathrm{y}} \times \mathrm{M} \\
& \mathrm{N}_{\mathrm{x}}: \text { 縦線本数 }(\text { イン当り) } \\
& \mathrm{N}_{\mathrm{y}} \text { : ワイヤー表面横線本数（インチ当り） } \\
& \mathrm{M} \text { : 繊維支持点係数 }
\end{aligned}
$$

(4) F. S. I. (Fiber Supporting Index)

R. L. Beran により提唱されたもので，纎維支持フ レームより各種ワイヤ一の縦横線の支持係数を求め, 縦横目数に関連づけて各種ワイヤーの繊維支持性を評
価しようとするもので，次式により計算される。 F. S. I. $=2 / 3 \times\left(\mathrm{A} \times \mathrm{N}_{\mathrm{x}}+2 \times \mathrm{B} \times \mathrm{N}_{\mathrm{y}}\right)$
$A$ : 縦線繊維支持係数
$\mathrm{B}$ ：横線繊維支持係数

注） 品種別係数は表 2 〜 5 参照

表 10 に各種ワイヤーの上記数值比較を示す。

(1) 1 重織

伸び特性改善も含めて縦線密度を上げ，沪水性を考 慮して横線を配しているので, 緎維支持点間距離は長 いが, 縦線間の距離を短かくすると同時に線に水平方 向のクリンプを付け表面空間が直線的にならないよう にして，繊維支持性を改善している。縦線本数が多い ため概して F. S. I. の数值は良い。

しかし目空きがあるため脱水力が直線紙層に働くの で，一般の横線摩耗型の場合，繊維支持性は多重織と 比較して劣り, リテンションを始めとした前記問題が 発生しやすい傾向にある。

そのため特に繊維の支持性と沪水性を要求される ティシュ抄造用ワイヤーは横線本数を縦線本数のそれ

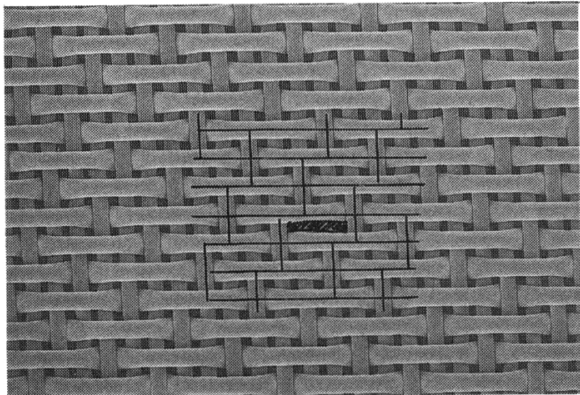

写真 4 ティシュ抄造用ワイヤ一表面 拡大写真

\begin{tabular}{|c|c|c|c|c|c|}
\hline 品種 & OS-H 80 & $(\mathrm{SS}-500)$ & $\mathrm{LL}-500$ & $\mathrm{LL}-40 \mathrm{E}$ & $\mathrm{TT}-400 \mathrm{~S}$ \\
\hline シャフト数 & 4 シャフト & 8 シャフト & 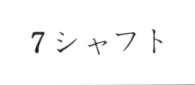 & 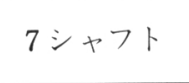 & $\begin{array}{l}\mathrm{U}: 2 \text { シャフト, } \\
\mathrm{L}: 5 \text { シャフト }\end{array}$ \\
\hline 目 数 & $91 / 60$ & $160 / 60 \times 2$ & $160 / 60 \times 2$ & $155 / 90 \times 1.5$ & $\begin{array}{l}\mathrm{U}: 70 / 70 \\
\mathrm{~L}: 70 / 70\end{array}$ \\
\hline 支点間距離 & 1.270 & 0.847 & 0.847 & 0.564 & 0.363 \\
\hline $\begin{array}{c}\text { 表面空間寸法 } \\
(\mathrm{A} \times \mathrm{B})\end{array}$ & $0.104 \times 1.067$ & $0.306 \times 0.667$ & $0.147 \times 0.667$ & $0.147 \times 0.414$ & $0.193 \times 0.203$ \\
\hline 支 持 点 数 & 423 & 372 & 425 & 497 & 781 \\
\hline F.S.I. & 100.7 & 90.0 & 102.8 & 136.9 & 141.3 \\
\hline
\end{tabular}

OF-H 76 ( 1 重織： 5 シャフト)

図 10 繊維支持点距離と表面空間の状況

表 10 各種ワイヤ一表面性評価数值比較表 


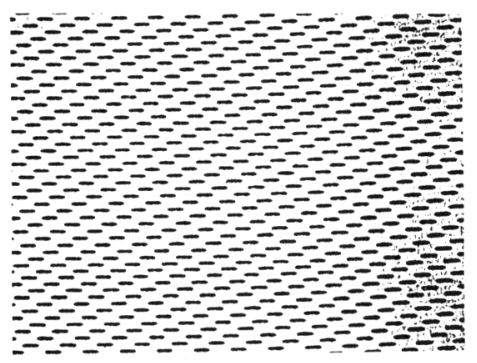

図 $11 \mathrm{OF}-\mathrm{H} 76$ 表面プリント拡大図

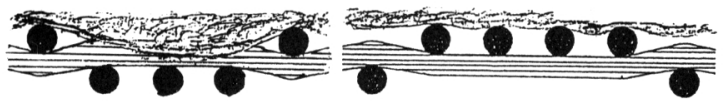

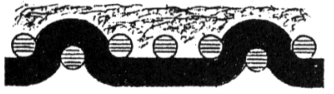

横線摩耗型
4 シャフトサテン織

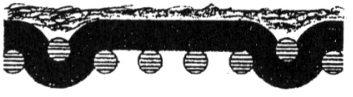

5 シャフトサテン織

縦線摩耗型
図 12 横線摩耗型と縦線摩耗型の繊維支持状況

より多くして，縦線摩耗型で使用される。ただしワイ ヤーマーク，寿命に難があるので一般的でない。写真 4 に表面拡大写真と図 11 に表面プリントマーク，図 12 に横線摩耗型と縦線摩耗型の繊維支持状況を示し た。

\section{(2) 2 重織}

沪水は主にボイドスペースを通して行われるため, 脱水力が直接紙層に働かないので瀻維の支持性は良く, 効果は認められている。7シャ.フトは目数が同じ場合, 8 シャフトに比較して各種数值が良いので繊維支持性 には有利である。14 シャフト, 16 シャフトはそれぞれ 7 シャフト， 8 シャフトに順じる。

(3) 2.5 重織

2 重織より各数值とも良好であり, 効果も実証され ている。

(4) 3 重織

上層網は繊維支持性の最も良好な平織であるため, 各数值とも優れており, 表面性については最も理想的 なワイヤーである。

図 13 は配向性抄紙機を利用して各種ワイヤーの歩 留り率を調査し, 各 F. S. I. との関係を示しているが, 相関関係があると考えられる。

その他の評価方法としては, 抄造された紙の表面三 次元粗さ測定 (図 14 参照), 紙の透過光をコンピュー ターにより画像処理を行い, 地合評価およびワイヤー

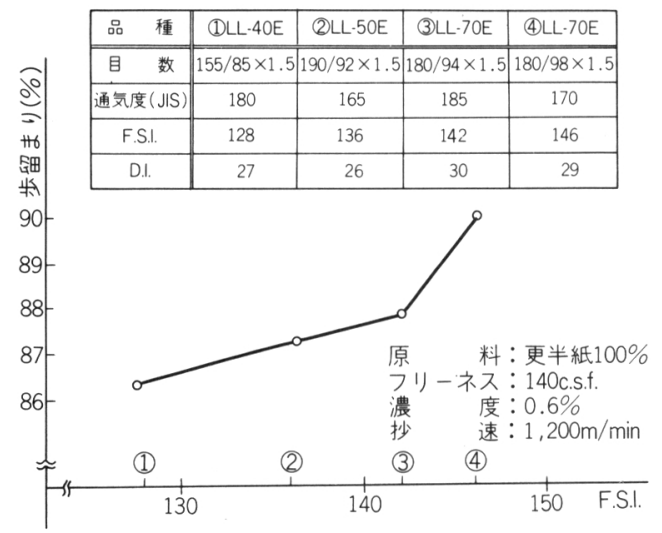

図 13 品種別 F. S. I. と歩留り量の関係

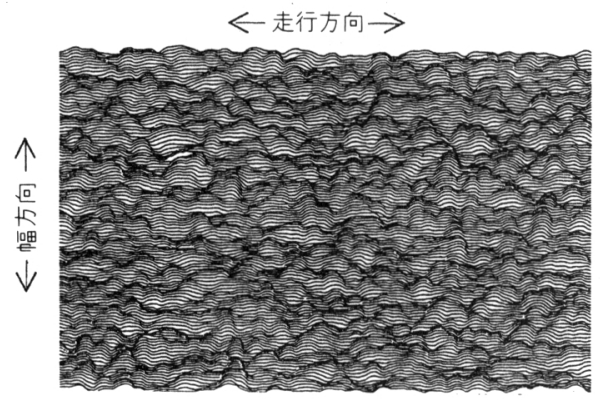

LL-40E(2.5重織：フシャフト)

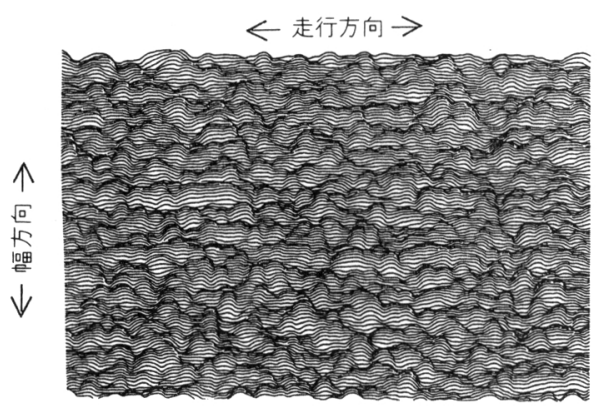

TT-4000 ( 3 重織：表面2シャフト)

図 14 紙の表面粗さ

マークの抽出等を行っている (図 15 参照)。

3.3 ワイヤーの沪水性

抄紙用ワイヤーは抄造過程に大量の水を除去せねば ならないため, 沪水性能は非常に重要な機能の一つで ある。

沪水はワイヤーの目空き空間およびボイドスペース によって行われるが，1 重織， 3 重織の場合は両者か 同時に作用し， 2 重織, 2.5 重織の場合は主にボイドス ペースにより行われる。 


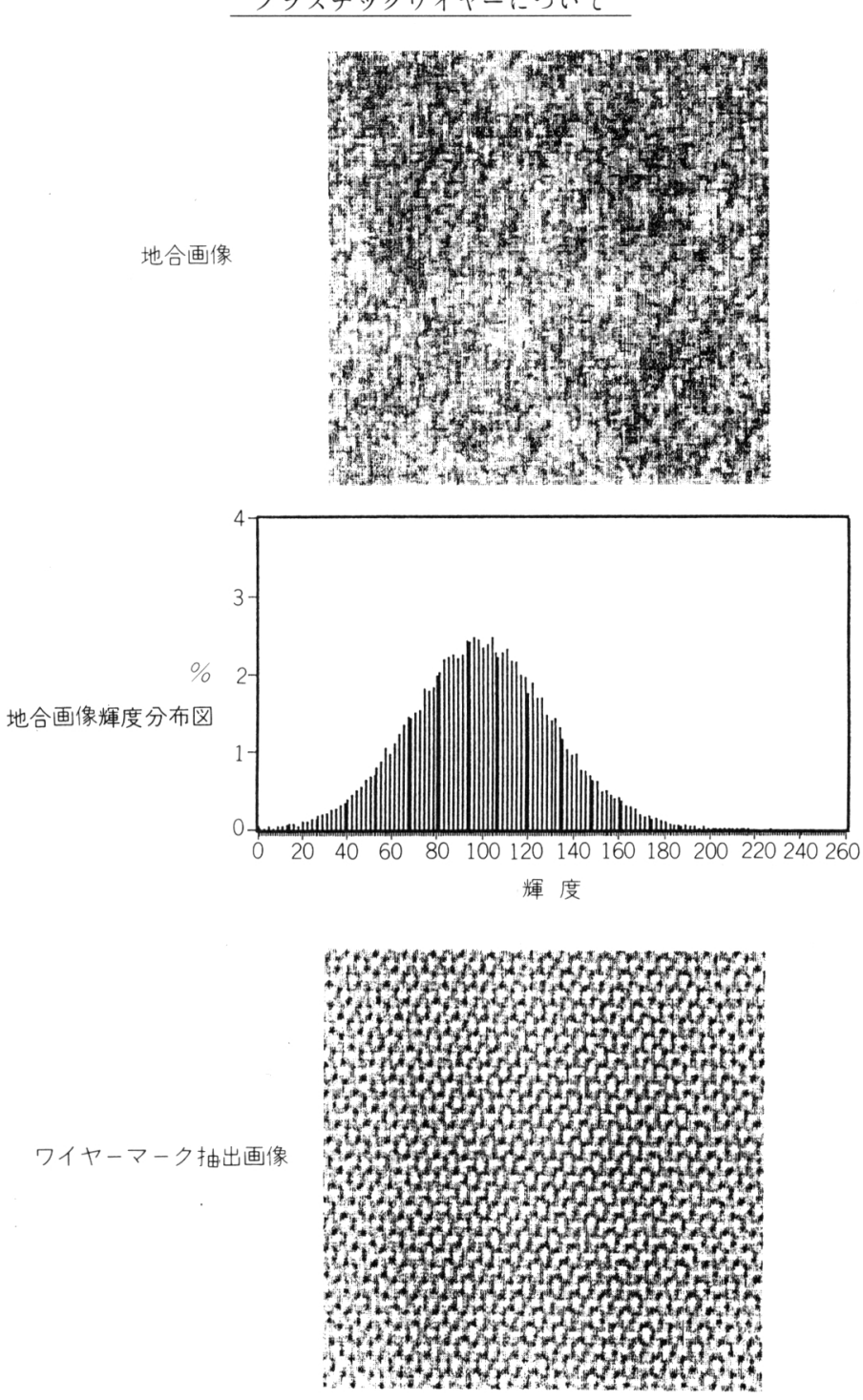

図 15 コンピューターによる画像処理

図 16 はレーザーでワイヤーオープネス角度を測定 したものである。1 重織の目空きがあるため走行方向 (MD), 幅方向 (CMD) とも垂直方向のオープネスが 大きい。2 重織 (8シュフト) 2.5 重織 (7シャフト) は走行方向に若干の差があるが，幅方向は図のように それぞれシャフト特有のオープネス角度を持っている のが認められる。

このことは 1 重織等目空きのある場合は紙層に直接 脱水力が作用するが， 2 重織等多重織の場合は水がワ イヤーを通過する際, 方向が変化し脱水速度を減少さ せるため紙層に過度な脱水力が作用しないため, リテ ンション等に有利なことを示している。

ワイヤーの沪水性の評価としては一般に通気度が使
用されている。これは一気圧の空気が単位時間内にワ イヤーを通過した量で示される。単位としてはJIS $\left(\mathrm{CC} / \mathrm{cm}^{2} / \mathrm{sec}\right), \mathrm{CFM}\left(\mathrm{ft}^{3} / \mathrm{ft}^{2} / \mathrm{min}\right), \mathrm{m}^{3} / \mathrm{m}^{2} / \mathrm{hr}$ があ り換算は次式で行う。

JIS 通気度 $=0.508 \times \mathrm{CFM}$

JIS 通気度 $=0.031 \times \mathrm{m}^{3} / \mathrm{m}^{2} / \mathrm{hr}$

他に沪水度もあるが, これは空気の代わりに水を使 用したもので, 図 17 に示すように通気度と相関関係が ある。

しかし，抄紙条件は原料および内填材の配合，濃度， 抄紙機の脱水性能等非常に多岐にわたっており, 使用 ワイヤーの諸特性との関わりもあるため複雑である。 紙層形成とのワイヤーの繊維支持性を関連づけ， ワ 
OS-H80(1重織：4シャフトサテン織)
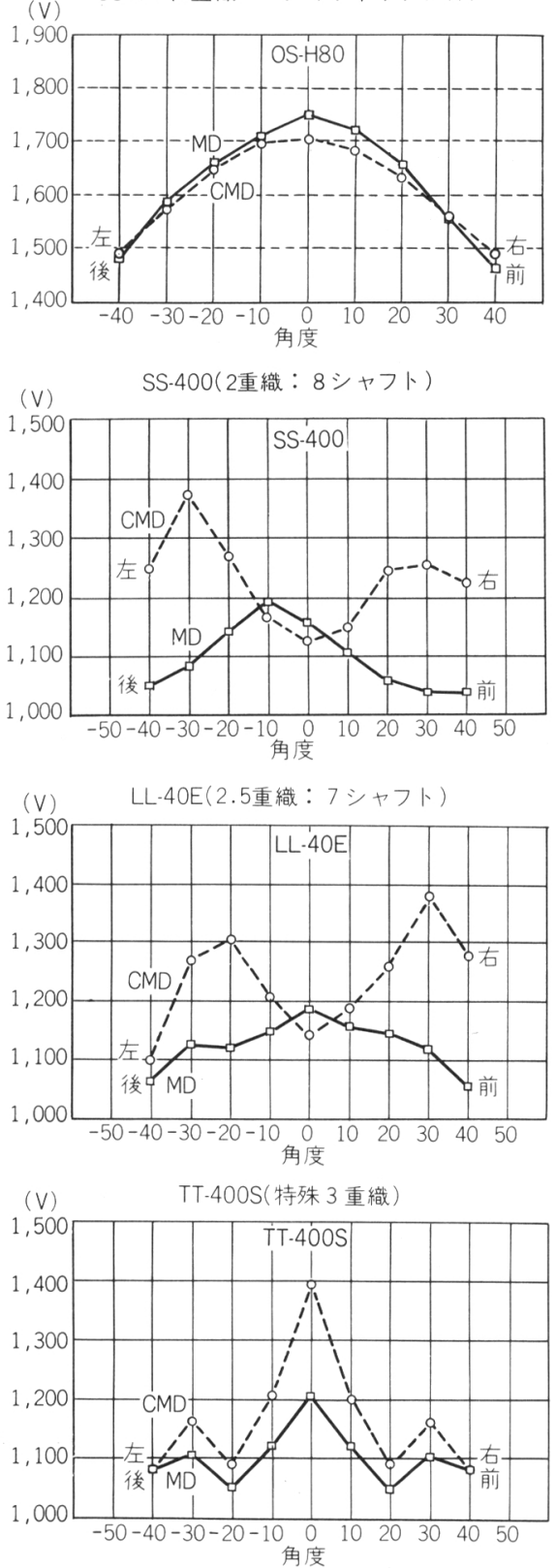

図 16 レーザーによるワイヤーのオープネス测定

イヤーの沪水性を評洒したものにD.I. (Drainaqe Index)がある。これは Beranの繊維支持係数と通気度 (CFM) の関係で次式により計算される。
D. I. $=\mathrm{CFM} \times \mathrm{N}_{\mathrm{y}} \times \mathrm{B} \times 10^{-3}$

表 11 に各種ワイヤーの沪水性評価の数值と図 18 に 通気度，F. S. I., D. I. の関連を示したが，緎維支持形 態が沪水性に影響することが分かる。現在ワイヤー間

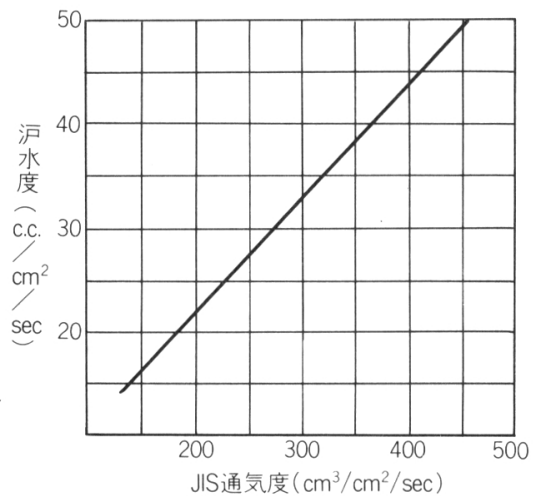

図 17 通気度と沪水度の関係

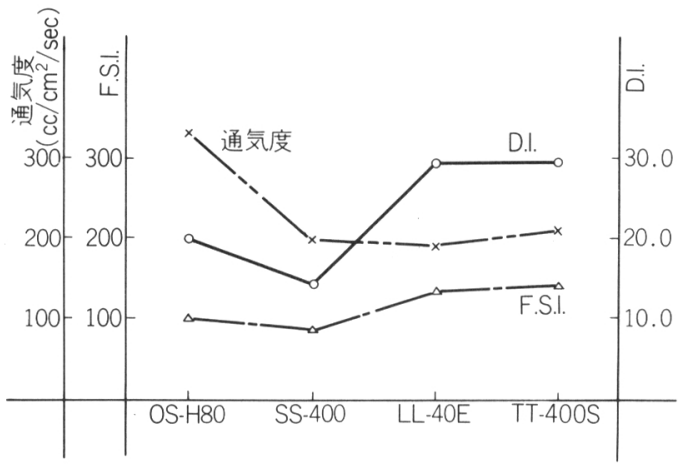

図 18 品種別通気度, F. S. I., D. I. の各数值比較

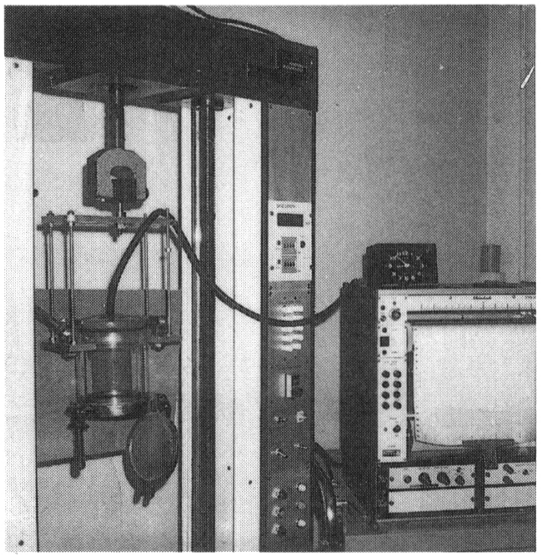

写真 5 沪水テス卜機

の比較をする場合，参考値として使用されている。

写真 5, (図 19 参照) のようなワイヤー沪水性測定 機（自社製）を使用して，各種ワイヤーの静的沪水速 度（沪水量と時間の関係）を調査した結果を図 20，21 に示している。罒より水の場合，沪水速度は通気度に 
表 11 各ワイヤーの沪水性評価数值比較

\begin{tabular}{|c|c|c|c|c|}
\hline 品種 & OS-H 80 & SS-400 & LL-40 E & $\mathrm{TT}-400 \mathrm{~S}$ \\
\hline シャフト数 & 4 シャフト & 8 シャフト & 7 シャフト & $\begin{array}{l}\mathrm{U}: 2 \text { シャフト, } \\
\mathrm{L}: 5 \text { シャフト }\end{array}$ \\
\hline 線 & $0.175 / 0.20$ & $\begin{array}{l}0.17 / 0.17 \\
/ 0.22,0.22 \mathrm{~N}\end{array}$ & $\begin{array}{l}0.17 / 0.13,0.17 \\
/ 0.22,0.22 \mathrm{~N}\end{array}$ & $\begin{array}{l}0.17 / 0.16 \\
0.20 / 0.22,0.22 \mathrm{~N}\end{array}$ \\
\hline 数 & $91 / 60$ & $155 / 58 \times 2$ & $155 / 90 \times 1.5$ & $70 / 70,70 / 70$ \\
\hline 網厚 & 0.42 & 0.68 & 0.69 & 0.83 \\
\hline 空 間 率 & $19.7 \%$ & - & - & $\begin{array}{l}\mathrm{U}: 29.7 \% \\
\mathrm{~L}: 17.7 \%\end{array}$ \\
\hline 立体空間率 & $57.1 \%$ & $56.1 \%$ & $57.0 \%$ & $58.4 \%$ \\
\hline $\begin{array}{c}\text { 立体空間体積 } \\
\left(\mathrm{cm}^{3} / \mathrm{m}^{2}\right)\end{array}$ & 230 & 385 & 380 & 489 \\
\hline 通気 度 & 330 & 195 & 190 & 210 \\
\hline F.S.I. & 100.0 & 87.1 & 132.4 & 140.0 \\
\hline D.I. & 19.8 & 14.1 & 29.3 & 29.4 \\
\hline
\end{tabular}

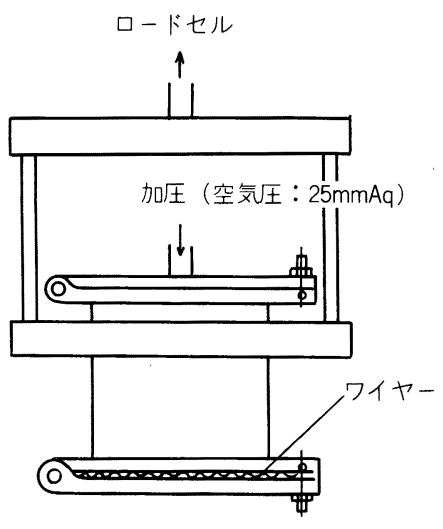

図 19 脱水比較テス夕ー
ほぼ比例し, パルプ混合液の場合は D. I. に近似的な関 係がありそうである。

しかし抄紙機上では実際には動的であり，ワイヤー へ各種の脱水力が作用する。すなわち初期時のジェッ 卜流の衝突による加圧脱水力, フォイル等脱水機器の 吸引力と裏面のウォーターフィル搔き落しによって生 じる反力との間で発生する脈動を伴った吸引脱水力 (図 22 参照), 2 枚のワイヤーのテンションとロール径 の関係により発生する面圧の絞り効果を伴い，ロール 回転による遠心力脱水 (図 23 参照)，円弧上に配置さ れたシューによる脈動と絞り効果を伴った脱水，サク ションボックスによる強制脱水等各種の脱水方式があ

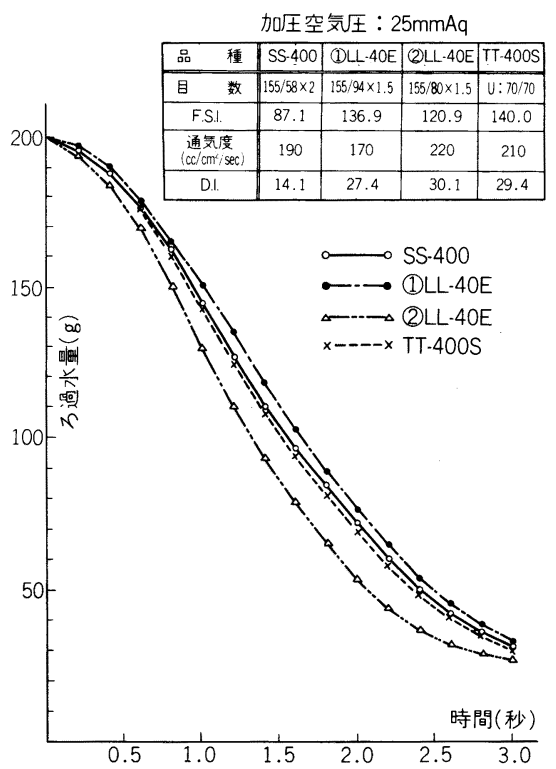

図 20 水による各種ワイヤーの沪過速度の比較

る。

前述の如く原料の配合も複雑であり， かつスラリー の粘性も無視出来ない。

一方，紙層の形成が順次行われるに従って，紙層を 通した脱水となるためワイヤーに対する負荷も増加す る。そのためワイヤーの伸び特性, 剛性, 表裏面の形 状, 幅方向のテンションプロファイルも均一な沪水性 


小林㞎雄

能を確保する意味で重要である。

以上述べた如く, ワイヤーの沪水性能評価方法は難 かしく, 通気度は初期の加圧脱水時等限度された領域 では有意性はあるが，総体の沪水評価としては疑問が ある。

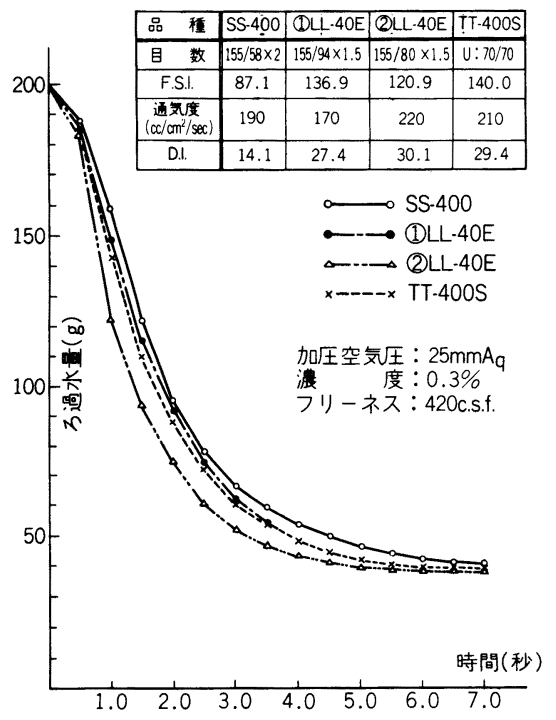

図 21 LBKP パルプ液による各種ワイヤーの ろ過速度の比較

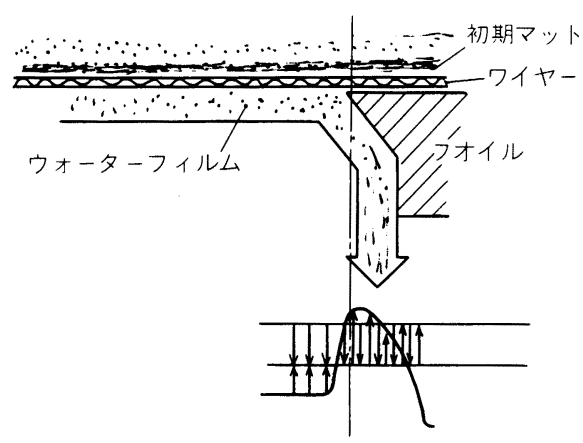

図 22 フオイルの脱水

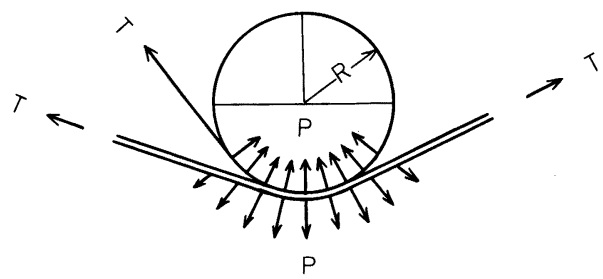

$$
\text { 脱水圧力 }=\frac{\text { 網の張力 } T}{\square-ル の \text { 半径 } R}
$$

図 23 ロール脱水 


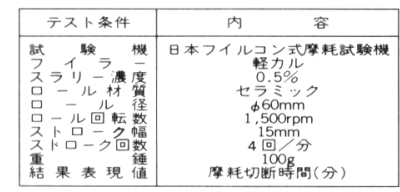

摩耗切断時間(線径: 0.22)

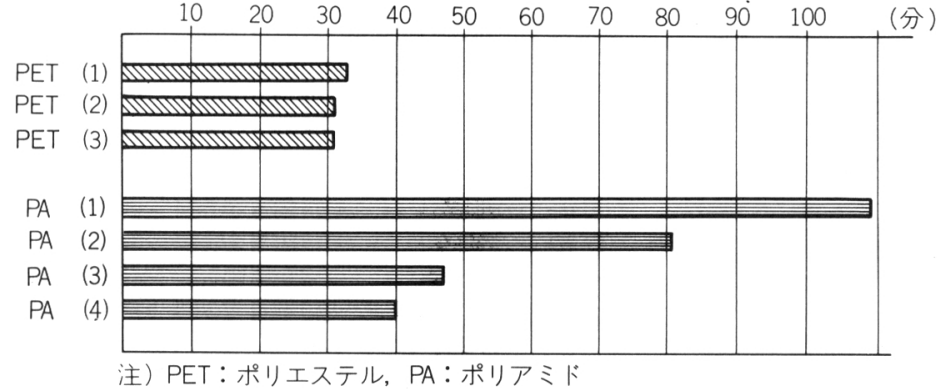

図 24 各種ポリエステルとポリアミド線材の摩耗比較

表 12 同一品種ワイヤ一の線材および摩耗体積に よる摩耗時間比較

\begin{tabular}{c|c|c|c}
\hline \multirow{2}{*}{ ワイヤー品種 } & \multicolumn{3}{|c}{ LL-40 E } \\
\cline { 2 - 4 } & 未交織品 & \multicolumn{2}{|c}{ 交織品 } \\
\hline 線 径 & $\begin{array}{l}0.17 / 0.13,0.17 \\
0.22\end{array}$ & \multicolumn{2}{|c}{$\begin{array}{c}0.17 / 0.13,0.17 \\
0.22,0.22 \mathrm{~N}\end{array}$} \\
\hline 目 数 & $155 / 90 \times 1.5$ & $155 / 90 \times 1.5$ \\
\hline $\begin{array}{c}\text { 摩耗体積 } \\
\mathrm{mm}^{3} / \text { 吋 }\end{array}$ & 21.0 & 22.1 & 162 \\
\hline $\begin{array}{c}\text { 摩耗時間 } \\
\left(\begin{array}{l}\text { (時間) } \\
\hline\end{array}\right.\end{array}$ & 2.13 & 5.47 & 4.47 \\
\hline
\end{tabular}

注）日本フイルコン式摩耗試験機使用

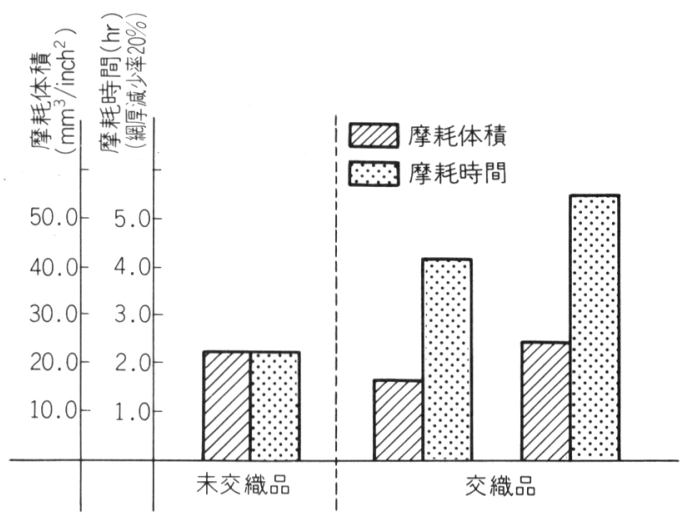

図 25 同一品種ワイヤーの摩耗比較

写真 6 に 7 シャフト, 8 シャフト, 16 シャフトの摩 耗面横線の形状写真を示したが, 7 シャフトに比較す ると形状，摩耗体積とも 8 シャフトに優位性があり,

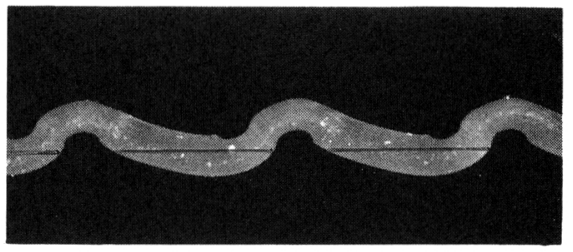

LL-40 E (2.5 重織： 7 シャフト)

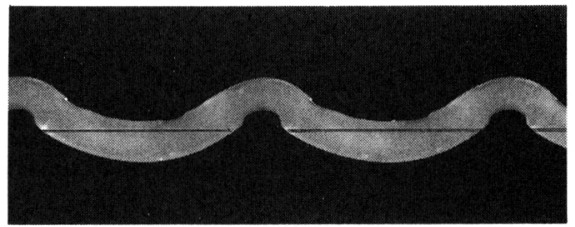

SS-400（2 重織：8シャフト)

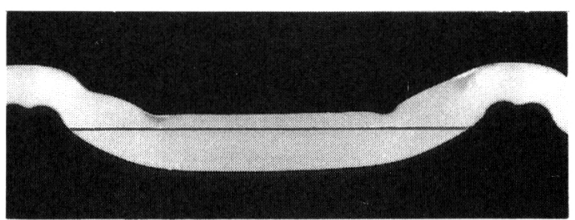

SS-4 BE (2.5 重織：16 シャフト)

写真 6 各品種の磨耗面横線形状 $(\times 30)$

16 シャフトは摩耗体積が増大するので耐摩耗性のみ 考えると非常に有利であることが分かる。

耐摩耗性を向上させるために横線径を太くする要請 もあるが，ワイヤーは織組織であるため線径, 目数等 により限定された範囲があり，太くすることによりク リンプが小さくなり, 摩耗体積を減少させ逆効果とな る場合もある。 
1208

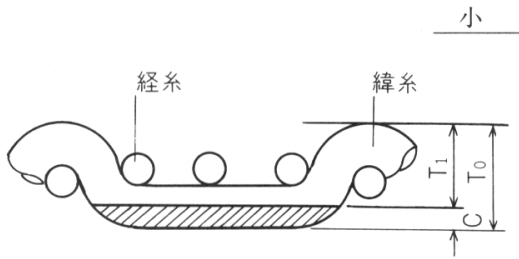

図 26 絧厚減少率

ワイヤーの摩耗限界については種々の説があるが, 一般的には網厚減少率で管理するのが便利である。

網厚減少率 $=\mathrm{T}_{0}-\mathrm{T}_{1} / \mathrm{T}_{0} \times 100 \%$ （図 26 参照） 普通摩耗限界の網厚減少率としては

1 重織 : $25 \sim 35 \%$

多重織：20２5\%

を参考值としている。

その他, 表面繊維支持性の良いワイヤーはリテン ションが改善され, 填料等のワイヤー裏面への流出が 少なくなるため摩耗に対して有利であり, 伸び特性, 風性も脱水機器への過度な接触を防ぐ意味から重要で ある。

一方，使用サイドにおいては，接触材の材質および 表面性, 金属ロールの表面の腐食等の状況, クーチロー ルとターニングロールの負荷配分, 急速脱水を避ける 等は配虑されるべきであり，特にドライになりやすい 部分（例：両耳脱水境界部等）にミストシャワー等で

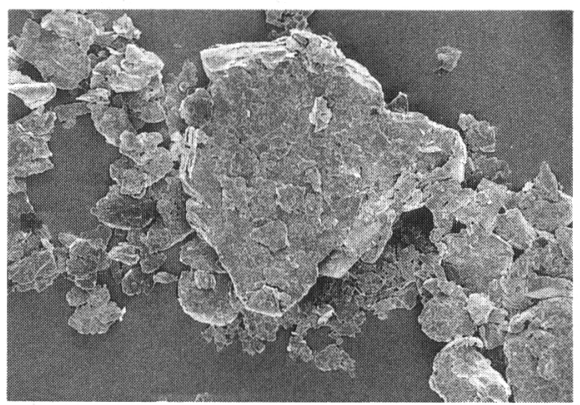

タルク

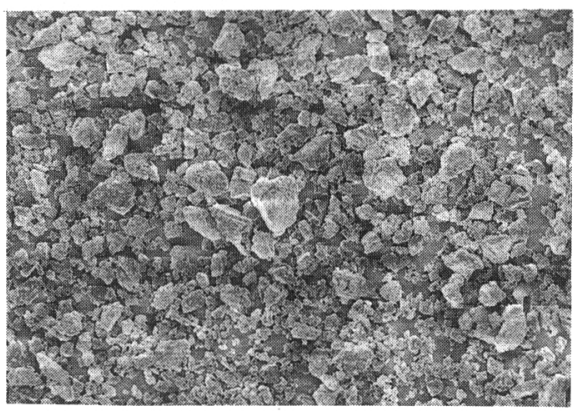

炭酸カルシウム

写真 7 塤料の拡大写真 $(\times 1,000)$
表 13 塡料による摩耗時間比較

\begin{tabular}{|c|c|c|c|c|}
\hline \multirow{3}{*}{$\begin{array}{l}\text { ワイヤ } \\
\text { 一品種 }\end{array}$} & 品 & 種 & \multicolumn{2}{|c|}{ SS-400 } \\
\hline & 線 & 径 & \multicolumn{2}{|c|}{$\begin{array}{l}0.17 / 0.17 \\
/ 0.22,0.22 \mathrm{~N}\end{array}$} \\
\hline & 目 & 数 & \multicolumn{2}{|c|}{$155 / 58 \times 2$} \\
\hline \multirow{3}{*}{ 墴料 } & 品 & 種 & $\mathrm{CaCO}_{3}$ & タルク \\
\hline & & $\%)$ & $94<$ & $85<$ \\
\hline & & & $\begin{array}{c}350 \text { mesh } \\
0.0\end{array}$ & $\begin{array}{c}200 \text { mesh } \\
0.1>\end{array}$ \\
\hline \multicolumn{3}{|c|}{ 摩耗時閴(時間) $)$} & 3.0 & 28.0 \\
\hline
\end{tabular}

潤滑する必要がある。

ワイヤーの摩耗にとって影響を与えるものに填料の 品質がある。写真 7 は夕ルクと炭酸カルシウムの拡大 写真である。タルクは粒子が比較的大きく, 形状は鱗 型であり鋭角面が見られないが，炭酸カルシウムは粒 子が細かく，形状に鋭角面が見られる。

表 13 に上記写真の填料による摩耗試験の結果を示 しているが, 明らかに炭酸カルシウムの摩耗進行が速 いことが分かる。中性抄紙の増加とともに炭酸カルシ ウムの質の向上が四られているが，ワイヤーについて もリテンション効果の良い繊維支持性を有したものの 選定が望ましい。

\section{5 ワイヤーの活れ}

プラスチックワイヤーの欠点に活れがある。その原 因としてはポリエステルは溌水性を有するため，污れ が線材表面に付着しやすいためであり，ポリアミドは 吸水性があるため有利であるが，その物性から使用は 限定される。また組織剛性も金属ワイヤ一に比較する と難があり, かつ組織構造も密であるため, 污れ, 纎 維の刺り込みが発生しやすい。

污れは脱水不良等抄紙条件, 操業条件にも影響があ り, 社会情勢として再生紙使用の高まりも予想される 状況下污れ対策も重要である。

ワイヤーでの対策としては, 表面密度, 組織剛性を 高め, 污れ等が組織内へ進入することを防ぐとともに, 構造は洗浄効果が上るようにすることが重要である。

洗浄効果は目空きがあるワイヤーが有利であるが, その他の特性とも関連があるため総合評価として考え るべきである。

しかし污れの基本的原因はその線材質によるため, ワイヤーの構造等そのものだけでの解決は難しい。そ のため研究開発されたのが樹脂加工である。 
表 14 樹脂加工品と未加工品の剥離テスト

\begin{tabular}{c|c|c}
\hline \multirow{2}{*}{ 品 種 } & \multicolumn{2}{|c}{$\mathrm{LL}-40 \mathrm{E}$} \\
\cline { 2 - 3 } & 樹脂加工品 & 未加工品 \\
\hline $\begin{array}{c}\text { 剥離強度 } \\
(\mathrm{g} / \mathrm{cm})\end{array}$ & 16.0 & 67.0 \\
\hline
\end{tabular}

注）上記試験は 48 時間洗浄後のワイヤーを使用

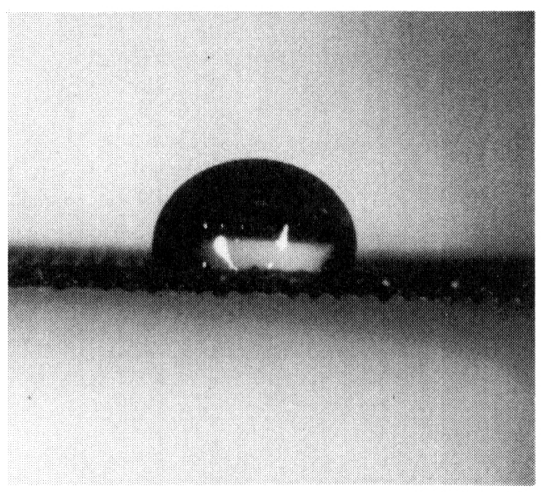

未加工品

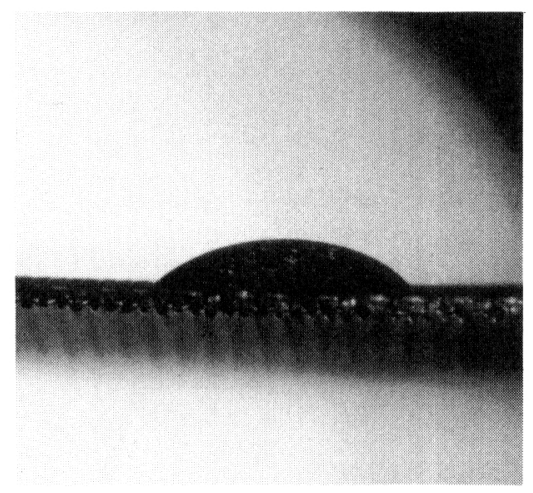

樹脂加工品

写真 8 ワイヤー上に水滴を落とした 状態（ワイヤー：LL-40 E)

樹脂加工は金属イオンを吸着させたカチオン交換性 の合成樹脂被覆を線材表面に形成し, 線材表面が常に 湿潤状態になるようにして污れの付着を防ぐ方法であ る。表 14 はガムを付着させたテープを張り付け剥離強 度を測定したものである。写真 8 はワイヤー面に水滴 を落した瞬間の状態で, 表 15 にその時の濡れ性比較の ため水滴の接触角度及び偏平率を調查したものである。 共にワイヤーの表面状態が親水性に変化し, 污れの付 着が改善されたことが分かる。

樹脂加工は縦横線の接触部を固定させるため, 剛性 等の改善に効果がある。弊社の樹脂加工は日本はもと より諸外国で特許が成立しており高い評価を得ている。
表 15 樹脂加工品と未加工品の濡れ性テスト

\begin{tabular}{c|c|c}
\hline \multirow{2}{*}{ 品 種 } & \multicolumn{2}{|c}{$\mathrm{LL}-40 \mathrm{E}$} \\
\cline { 2 - 3 } & 樹脂加工品 & 未加工品 \\
\hline 接触 角 $($ 度 $)$ & $57.2^{\circ}$ & $110.5^{\circ}$ \\
\hline 偏平率 $(\mathrm{a} / \mathrm{b})$ & 5.258 & 1.853 \\
\hline
\end{tabular}

注）接触角およU゙偏平率は下図参照

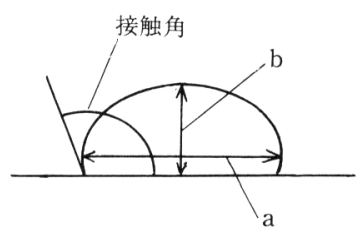

偏平率 $=\mathrm{a} / \mathrm{b}$

使用にあたっては洗浄装置も重要であり，高圧摺動 ニードルシャワーが広く使用されている。1 重織等目 空きのあるワイヤーは洗浄効果は良いが， 2 重織等は 目空きがほとんど無く, 組織密度も高いため洗浄装置 の強化も必要である。

シャワー効果は一般にワイヤーを貫通する水量と考 えられている。図27に各種ワイヤーのレーザーによる オープネス角度とシャワーの貫通水量との関係を対比 させたが, 目空きのある 3 重織は走行方向, 幅方向と もオープネスと水量に相関関係がある。しかし 2 重織 の場合，走行方向に相関関係が見られるが，幅方向は 縦線密度の関係で角度を付けると水のは数返りで量が 多くなり，貫通する水量は垂直方向が多い結果となっ ている。

故に 2 重織等の場合はワイヤー裹面へのシャワーは 垂直方向から，ワイヤー表面へのシャワーは幅方向へ 角度を付けて設置し，水のはね返りを利用して污れを 除却するのも一つの方法と考えられる。実際に図 28 の ようにロール面上でシャワーをかけ，水のは衩返りを 利用した洗浄方法も行われており, 効果が報告されて いる。

\section{6 ワイヤーの走行性}

抄紙用ワイヤーの操業性にとって走行性安定性は必 要な条件の一つである。特に移動は 1 重織, 3 重織で は比較的問題にならないが，2 重織等多重織の場合， 条件にもよるが時として発生する。

これはワイヤ一裏面に表面と同様織組織固有の綾の パターン (図 29 参照) があり, 一方, 脱水機器はワイ ヤー進行方向にたいして直角に設置されているため, その上をワイヤーが擢動するときの関係で幅方向に移 動力が働く。また前述のように 2 重織等はワイヤーの 

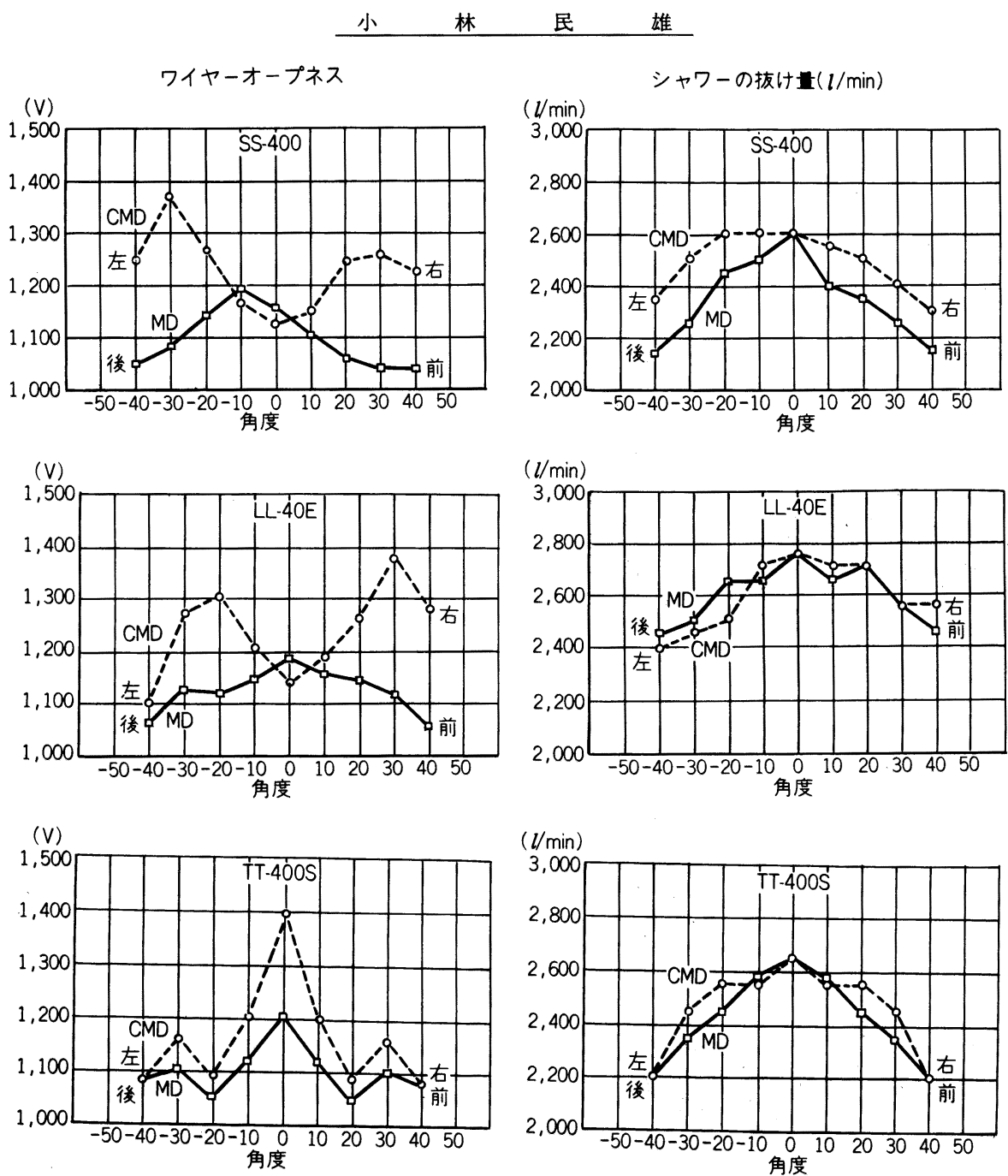

図 27 オープネス角度とシャワー貫通量との比較

シャワー条件

$$
\begin{aligned}
& \text { シャワーノズル }: 1.0 \mathrm{~mm} \\
& \text { シャワー圧 } \quad: 30 \mathrm{~kg} / \mathrm{cm}^{2} \\
& \text { ワイヤーーシャワー間距離 }: 100 \mathrm{~mm}
\end{aligned}
$$

替動：有

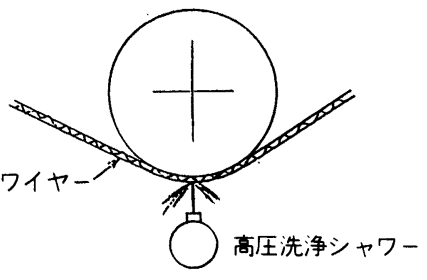

図 28 高圧洗浄シャワーの設置例
オープネスが幅方向に角度を有しているため初期の加 圧脱水時水の通過する影響も推定できる。

ワイヤー駆動力が高いときは移動は発生し難いが, 使用初期等摩耗が進行せず駆動ロール等にたいしてワ イヤー裏面の接触面積が小さいとき, 発生しやすい傾 向にある。特に前掲の写真の如く 7 シャフトは摩耗面 横線形状が 8 シャフトに比較すると, 初期の接触面積 が若干少ないので駆動力伝達に不利であり，移動が発 生しやすいことが推定出来る。

ワイヤー駆動力は張力に比例するための使用時のテ 


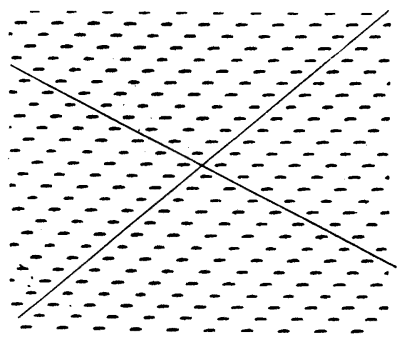

$\mathrm{SS}: 400$ (2重織：8シャフト)

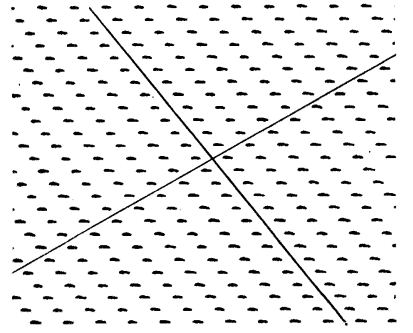

LL.400(2重織：7シャフト)

図 29 ワイヤー裏面のプリント困 ( 2 重織：7シャフト)

ンション管理は重要である。特に使用初期においては 初期伸びも若干発生するため充分注意する必要がある。

また幅方向に働く移動力が強い場合, 駆動力と合成 された力 (図 30 参照) がワイヤーの綾方向との相剩効 果により筋曲りとそれに伴う幅縮み等の現象が生ずる 危険もある。そのため使用に際しては, 各脱水機器, 接触するロール類（ダンデイロールも含む）の平行度 ならびに水平度, マシン表裏の周長, サクションボッ クスの表裏吸引度のバランスの管理も重要であり，ま たジェット流のワイヤーに対する衝撃力も配虑する必 要がある。

なおガイドロールがワイヤー裏面に接する場合，初 期移動が発生しやすいので，抱き角を出来る限り大き
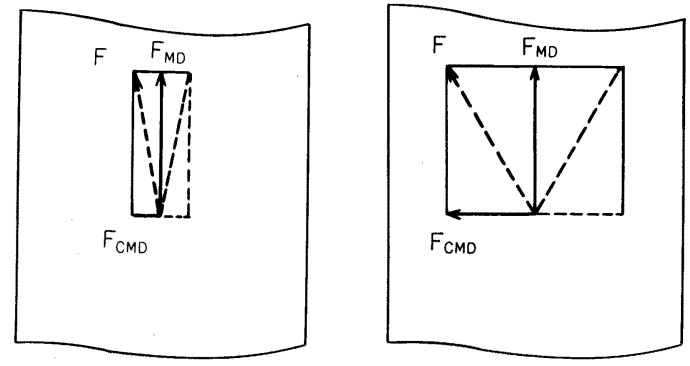

図 30 ワイヤー上に㗢くカ

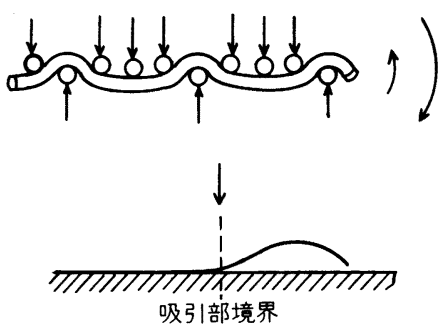

OS-H80(1重織：4シャフトサテン織)
くすることも望ましい。

ワイヤーでの対策として移動に関しては，製作時綾 方向を通常の逆方向とすることも有効で，もちろん伸 び特性，剛性は必要な条件であり，そのため樹脂加工 (表 9 参照) も効果がある。

耳カールも操業性にとって重要である。耳カールは ワイヤーの織組織に由来しており, 図 31 のように縦方 向張力と幅方向の反作用により発生する。そのため製 作工程ならびに特殊加工により対処している。

\section{7 ワイヤーの保水性}

ワイヤーの保水性は多重織が使用され始めてから特 に問題として提起されてきている。一般に 1 重織は目 空きがあり，網厚も薄くボイドスペースも小さいため 水の切れもよく問題は少なかったが，多重織は組織構 造および網厚からボイドスペースが大きく，その部分 に水を保持しやすい。

保水性はプレスパートへの湿紙水分増加ばかりでな く，シートリリース不良とそれに伴うファイバーキァ リーバック，ウオータースプラッシュによる紙質への 影響等の障害が指摘されており，特に高速マシンほど この影響は著しい傾向にある。

表 16 に各種ワイヤーのボイドスペースと静的保水 量の測定值を示しているが，共に相関関係がある。

図 32 はワイヤー走行装置（図33 参照）を使用して

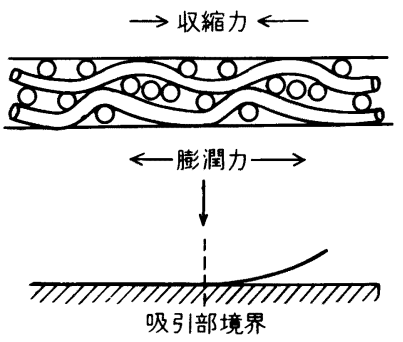

LL-500(2重織：7シャフト)

図 31 耳カールの発生原因 
表 16 各種ワイヤーのボイドスペースと静的保水量

\begin{tabular}{|c|c|c|c|c|}
\hline 品種 & OS-H 80 & SS -400 & LL-40 E & $\mathrm{TT}-400 \mathrm{~S}$ \\
\hline シャフト数 & 4 シャフト & 8 シャフト & 7シャフト & $\begin{array}{l}\mathrm{U}: 2 \text { シャフト, } \\
\mathrm{L}: 5 \text { シャフト }\end{array}$ \\
\hline 径 & $0.175 / 0.20$ & $\begin{array}{l}0.17 / 0.17 \\
/ 0.22,0.22 \mathrm{~N}\end{array}$ & $\begin{array}{l}0.17 / 0.13,0.17 \\
/ 0.22,0.22 \mathrm{~N}\end{array}$ & $\begin{array}{l}0.17 / 0.16 \\
0.20 / 0.22,0.22 \mathrm{~N}\end{array}$ \\
\hline 数 & $91 / 60$ & $155 / 58 \times 2$ & $155 / 90 \times 1.5$ & $70 / 70,70 / 70$ \\
\hline 網 & 0.42 & 0.68 & 0.69 & 0.83 \\
\hline $\begin{array}{c}\text { 立体空間体積 } \\
\left(\mathrm{cm}^{3} / \mathrm{m}^{2}\right)\end{array}$ & 230 & 385 & 380 & 489 \\
\hline 立体空間率 & $56.2 \%$ & $56.1 \%$ & $57.0 \%$ & $58.4 \%$ \\
\hline $\begin{array}{c}\text { 静 的保水量 } \\
\left(\mathrm{cm}^{3} / \mathrm{m}^{2}\right)\end{array}$ & 149 & 298 & 305 & 416 \\
\hline
\end{tabular}

\begin{tabular}{|c|c|c|c|c|c|c|}
\hline 種 & LV65 & OS.H80 & SS-400 & LL-40E & TT.4000 & TT.400S \\
\hline 数 & $65 / 65$ & $91 / 60$ & $155 ; 58 \times 2$ & $155 ; 90 \times 1.5$ & U:7075 & U:70:70 \\
\hline F.S.I. & 97.5 & 100.0 & 86.8 & 132.4 & 146.7 & 140.0 \\
\hline 網 厚 $(\mathrm{mm})$ & 0.53 & 0.42 & 0.68 & 0.69 & 0.91 & 0.83 \\
\hline 立体空間率 $(\%)$ & 57.1 & 56.2 & 56.1 & 57.0 & 61.0 & 58.4 \\
\hline $\begin{array}{c}\text { 静的保水量 } \\
\left(\mathrm{cm}^{3} / \mathrm{m}^{2}\right)\end{array}$ & 235 & 149 & 298 & 305 & 344 & 416 \\
\hline
\end{tabular}

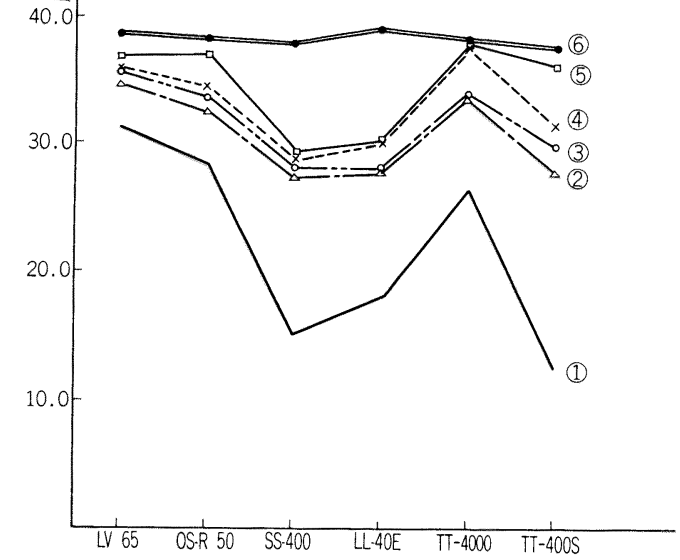

図 32 各種ワイヤー動的保水量のテスト

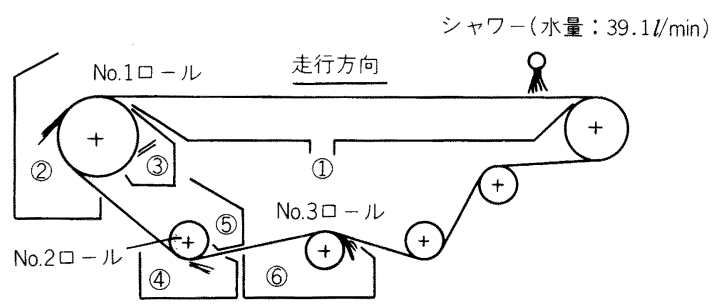

図 33 走行装置と脱水量測定位置
水による各種ワイヤーの保水性を動的に調査したもの であり, 各部の脱水量を積算している。この図より自 然脱水領域では, 脱水量は通気度にほぼ比例しており, ワイヤー沪水性で述べた初期脱水領域での通気度の有 意性が理解出来る。

各ワイヤーの比較では，No.1ロールにおけるスプ ラッシュの脱水量は金属ワイヤー, 1 重織に比較して 多重織は多く, ロール上に転移する水量は少ない。 No.2 ロールではスプラッシュは多重織が矢張り多く, ロール上に転移する水量も特殊 3 重織を除き少ない。 特に顕著なことは 2 重織, 2.5 重織の場合, ワイヤー表 面に設置されたNo.3 ロールでの脱水量が多いことで ある。

以上より金属ワイヤー，1重織は初期の自然脱水領 域の脱水量が多いため，その後の各部の脱水量は総体 的に少なく，初期脱水が良く；保水性が少ないと言之 る。

2 重織, 2.5 重織は初期の自然脱水領域での脱水量 が少ないため, No.1ロールでのスプラッシュ量が多 く, その後の各部での脱水量は少ないが, No.3 ロール での脱水量が急激に増加する。このことは沪水性で述 べた如く, 組織内の沪水経路の方向転換があり沪水速 度が減少するため, No.1ロールではワイヤー表面に 滞留した水が脱水され, その後走行状態から遠心力等 外力により, 内部の水が徐々に表面に押し出され, No.3 ロールでの脱水量が多くなると推定できる。

3 重織の場合は初期の自然脱水領域での脱水が多い 割合にNo.1, No.2 ロールでのスプラッシュ脱水量が 多く，このことは下層網に比較して上層網の目数が細 かいため，上層網に水が保持されやすい性質があると 


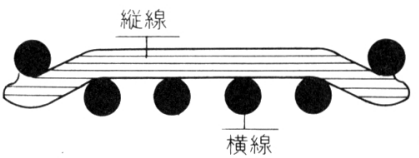

1 重織(5シャフトサテン織)

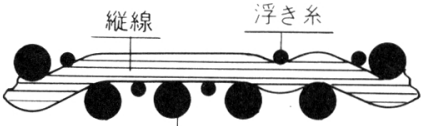

横線

図 $34 \quad 1.5$ 重織横断面困

推定される。

特殊 3 重織は初期の自然脱水領域での脱水が少なく, その後各部での脱水量が多くなっている。これは組織 構造から外力に順応して水が移動しやすい性質がある と想像される。

保水性はワイヤーの組織内に形成されたボイドス ペースの形状と水の表面張力と関連で発生すると考え られるが，抄造条件は複雑で粘性も考虑されるべきで あろう。

ワイヤーとしては脱水力等外力により, 組織内の水 の流動がスムーズに行われる組織構造が望まれるが, 諸特性との関連もあり；現状ボイドスペースに関連す る網厚等で対処している。

一方，使用にあたっては，デイフレクター等水切り 装置, ロールの設置ないしは位置およびワイヤーの接 触面の変更, エアーシャワーの設置, スプラッシュ保 護板等の設置により対処されている。

以上，抄紙用ワイヤーに要求される条件とプラス チックワイヤーの諸特性との関わりについて概要を述 ベな。

この視点から現在多品種のプラスチックワイヤーが 研究開発の結果実用化されているが改善要求も多い。

このため研究開発は重要であり, 開発部門の充実とと もに, 現状製品の改善はもとより新製品の研究開発を 積極的に進めている。その中で実用化テスト中の 1.5 重織を紹介したい。

これは当社オリジナル製品であり，前期した 1 重織 の利点, すなわち初期脱水性, 保水性が少ない, 洗浄 効果が良い等を考慮して, 欠点である紪維支持性を改 善したものである。

構造は写真 9 に示すように，5シャフトサテン織で 従来の横線を沪水性を配慮して織り込み繊維支持性を 改善すると同時に表面平滑性，剛性を改善するため組 織の 1 部を変えたものである（図 34 参照）。

現在板紙抄造にテスト使用されているが, リテン ション, 紙の平滑性, 地合等の改善が報告されている。 なお 1 重織組織全てに通用出来るように各種テストを 継続中である。

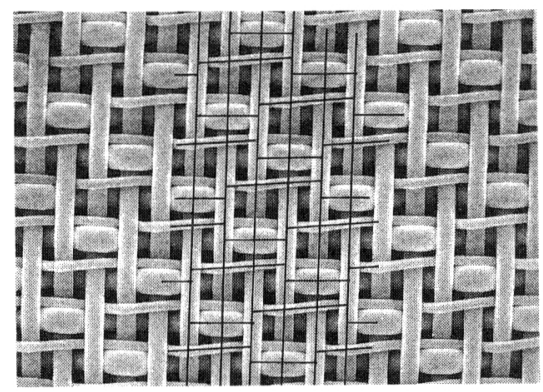

表面

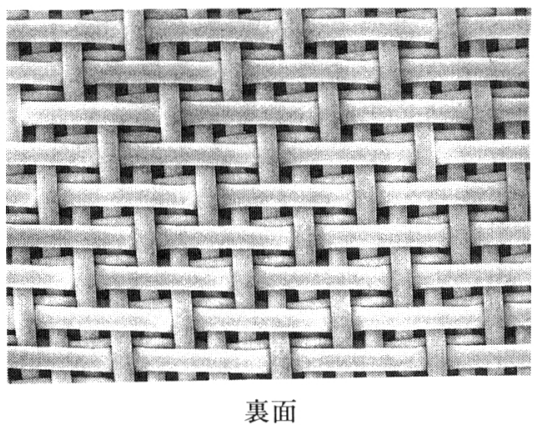

写真 91.5 重織表裏拡大写真 (OFE-H 50)

\section{あとがき}

抄紙用プラスチックワイヤーの今後については, 諸 特性の向上はもとより, よりファインメッシュの製品 品質および精度の向上, 新製品等が強く求められると 予想される。

そのため当社は開発部門の充実を始めとし，最新鋭 設備の継続導入と既設設備の改善, 生産技術の研究改 良, 品質管理体制のより強化をはかるとともに，お得 意先のご要望を適確に把握し, すみやかに対応できる よう技術サービス部門の拡充等体制づくりを積極的に 進めており，必ずやご期待にそえるものと確信してい る。

今後とも一層のご鞭撻とご愛顧をお願いする次第で ある。 